OPEN ACCESS

Edited by: Glenn T. Howe,

Oregon State University, USA

Reviewed by:

Cristina Nabais,

University of Coimbra, Portugal

Cyrille B. K. Rathgeber,

Institut National de la Recherche

Agronomique, France

*Correspondence:

Guillaume Charrier.

Department of Botany, University of

Innsbruck, Sternwartestrasse 15,

Innsbruck A-6020, Austria

guillaume.charrier@uibk.ac.at

Specialty section:

This article was submitted to Functional Plant Ecology,

a section of the journal

Frontiers in Plant Science

Received: 30 August 2014 Accepted: 01 April 2015

Published: 28 April 2015

Citation:

Charrier G, Ngao J, Saudreau M and Améglio T (2015) Effects of environmental factors and management practices on microclimate, winter physiology, and frost resistance in trees.

Front. Plant Sci. 6:259.

doi: $10.3389 /$ fpls.2015.00259

\section{Effects of environmental factors and management practices on microclimate, winter physiology, and frost resistance in trees}

\author{
Guillaume Charrier $^{1 *}$, Jérôme $\mathrm{Ngao}^{2,3}$, Marc Saudreau $^{2,3}$ and Thierry Améglio ${ }^{2,3}$ \\ ${ }^{1}$ Department of Botany, University of Innsbruck, Innsbruck, Austria, ${ }^{2}$ INRA, Clermont-Ferrand, France, ${ }^{3}$ Clermont Université, \\ Université Blaise Pascal, Clermont-Ferrand, France
}

Freezing stress is one of the most important limiting factors determining the ecological distribution and production of tree species. Assessment of frost risk is, therefore, critical for forestry, fruit production, and horticulture. Frost risk is substantial when hazard (i.e., exposure to damaging freezing temperatures) intersects with vulnerability (i.e., frost sensitivity). Based on a large number of studies on frost resistance and frost occurrence, we highlight the complex interactive roles of environmental conditions, carbohydrates, and water status in frost risk development. To supersede the classical empirical relations used to model frost hardiness, we propose an integrated ecophysiologically-based framework of frost risk assessment. This framework details the individual or interactive roles of these factors, and how they are distributed in time and space at the individualtree level (within-crown and across organs). Based on this general framework, we are able to highlight factors by which different environmental conditions (e.g., temperature, light, flood, and drought), and management practices (pruning, thinning, girdling, sheltering, water aspersion, irrigation, and fertilization) influence frost sensitivity and frost exposure of trees.

\footnotetext{
Keywords: frost resistance, carbon balance, water status, stress interaction, microclimate, environmental factors, anthropogenic impact, risk assessment
}

\section{Introduction}

Frost-related stresses strongly influence altitudinal and latitudinal plant distributions (Gusta et al., 1983; Koerner, 1998; Gansert, 2004; Larcher, 2005; Charrier et al., 2013a). Of different weather hazards, freezing events cause the greatest economic losses in agriculture (Snyder and Melo-Abreu, 2005; Snyder et al., 2005). A single freezing event can cause losses of hundreds of millions of dollars in fruit and tree production (Attaway, 1997). Most fruit species currently growing in temperate zones originate from warmer climates, especially Asia, e.g., walnut (Fornari et al., 2001), apple, pear, and plum trees. In the selective breeding process that began in the Pliocene (Manchester, 1989), high yield and strong pathogen resistance were the principal goals, rather than frost resistance (Fady et al., 2003). Although frost dramatically constrains life forms and generates enormous economic losses, it has not been as thoroughly studied as other biotic or abiotic stresses such as drought or herbivory. The main reason for this may be that damage occurs when trees seem to be inactive, and damage may become visible only in the subsequent growing season.

Frost risk (probability of frost damage) increases when hazard (probability of a given freezing temperature) coincides with vulnerability (frost sensitivity). Frost sensitivity is the converse of frost 
resistance. During the annual cycle of growth and dormancy, the transition periods in autumn and spring are the most risky. This is when plants are most vulnerable and there is a moderate probability of freezing. The probabilities of autumn and spring frosts are comparable (Spulak and Balcar, 2013). In autumn and spring, moderate freezing events can significantly damage trees, but during the winter, the temperatures that cause damage (i.e., frost resistance) are much lower than the temperatures that trees encounter (Larcher et al., 2010; Kollas et al., 2014).

Phenological processes are particularly important for frost avoidance in spring and autumn (Figure 1). Phenological stages (e.g., the induction and release of endodormancy and ecodormancy; Lang et al., 1987) control the exposure of vulnerable organs to frost (e.g., flushing buds, blooming flowers, and leaves of deciduous trees). Hence, dormancy induction and release occurs simultaneously with frost acclimation and deacclimation (Palonen and Linden, 1999; Charrier et al., 2011). After growth cessation, frost acclimation and endodormancy release are both regulated by low temperatures, whereas deacclimation and ecodormancy release are subsequently controlled by warmer, mild temperatures. Temperature is perceived within the bud, both for chilling and forcing (Bonhomme et al., 2013). However, in late successional species, photoperiod may also influence dormancy release and the timing of budburst (Basler and Koerner, 2012). Photoperiod exerts its greatest effect when chilling requirements have not been fulfilled (Laube et al., 2014). The "safety margin" (calculated as the difference between the temperatures that cause damage and minimum temperatures) is usually wide enough at the end of the ecodormancy period to avoid damage to flushing buds (Lenz et al., 2013). Nevertheless, frost damage can still occur (Rodrigo, 2000; Cittadini et al., 2006). At the warmer margins of cultivated areas,

\section{Terminology}

Ecodormancy: Temporary suspension of meristem activity controlled by environmental factors, i.e., temperature and photoperiod.

Endodormancy: Temporary suspension of meristem activity controlled by intrinsic factors, and released by chilling exposure, before the ecodormancy stage.

Exotherm: Latent heat (334 J.g $\mathrm{g}^{-1}$ ) released during the transition from liquid water to solid state: crystalline structure of ice being more stable than liquid water. The exotherm increases the temperature of the freezing organ.

Apoplastic water freezes at higher temperatures (high temperature exotherm) than intracellular water (low temperature exotherm).

Frost risk: Risk of frost damage is incurred when hazard (freezing event) meets vulnerability (frost sensitivity).

Girdling: Partial or total removal of phloem ring.

Hardening: Process by which an individual plant becomes tolerant to the

effects of freezing during a period of weeks to months.

Paradormancy: temporary suspension of meristem activity controlled by leaf on apical or axillary buds.

Pruning: Removing woody parts (including or sparing reproductive organs) from the canopy.

Radiative frost: Frost caused by radiative cooling, i.e., the process by which a body loses heat by thermal radiation, usually infrared.

Supercooling: Also known as undercooling, this is when the temperature of a liquid or a gas falls below its freezing point without it becoming solid.

Thinning: removing fruits or flowers either singly or in clusters. trees can experience insufficient chilling, which generates erratic patterns of flushing (Balandier et al., 1993; Bonhomme et al., 1999; Marafon et al., 2011; Chuine et al., 2014; Dantec et al., 2014).

At the individual-tree level, frost resistance is well documented. Many models are used to predict temporal changes in frost resistance (e.g., Fuchigami et al., 1982; Greer and Warrington, 1982; Leinonen, 1996; Poirier et al., 2010). However, trees are integrated organisms composed of repeated structures termed modules (Hallé et al., 1978; Kawamura, 2010). These modules (e.g., buds, shoots, branches) are histologically and spatially distinct, and located up to several meters apart. This organization results in heterogeneity in organ temperatures because of heterogeneity in microclimatic conditions (Frame A, Figure 2). At the intra-individual scale, spatial variability in frost resistance and hazard are also heterogeneous, from root system to apical buds (Charrier et al., 2013b). The consequences of frost damage for the aboveground vegetative plant parts have been less thoroughly researched than those affecting the economically important parts, such as flowers and fruits. However, the architecture of the aboveground portion of the tree influences temperature distribution (microclimate) and, therefore, potential damage. Across all plant parts, the shoot apical meristem plays a key role because temperature damage to it affects survival, ecological distributions (Nobel, 1980), and fruit production (Rodrigo, 2000). When apical buds are damaged, loss of apical dominance results in changes in growth patterns. The subsequent changes in the tree's architecture will, therefore, modulate local environmental conditions (e.g., light, temperature, and humidity), which, in turn, can influence carbon acquisition and pest development.

The productivity and sustainability of forest and orchard trees depend on growth processes. Growth is an integrative process controlled by environmental conditions and management practices. Irrespective of the plant species or location, frost-related stresses have similar consequences, generated by low temperatures, and extracellular or intracellular freezing. Trees use similar strategies to cope with these stresses, including avoidance and tolerance. Frost tolerance usually relies on osmotic control by cryoprotectants and free water content in the tissues. Yet, empirical relationships between environmental factors (e.g., temperature and photoperiod) and frost tolerance have often been used for modeling and forecasting purposes. In this review, we propose a conceptual framework (Figure 2) that explicitly includes the ecophysiological processes underlying frost risks. We first review the different symptoms caused by chilling and freezing (see Symptoms of Low Temperature Damage), and their temporal and spatial patterns (see Modulation of Frost Resistance). We then assess the different strategies used to cope with freezing stresses (see Strategies Driving Frost Resistance). Among these, we focus on the environmental determinants and management practices that influence the osmotic control strategy (see Environmental Factors and Management Practices Influencing Frost Risk). In particular, we detail how environmental factors and management practices interact with frost resistance and withincrown microclimatic conditions. This framework could be integrated on a pluri-annual timescale with cumulative sub-lethal stresses. 


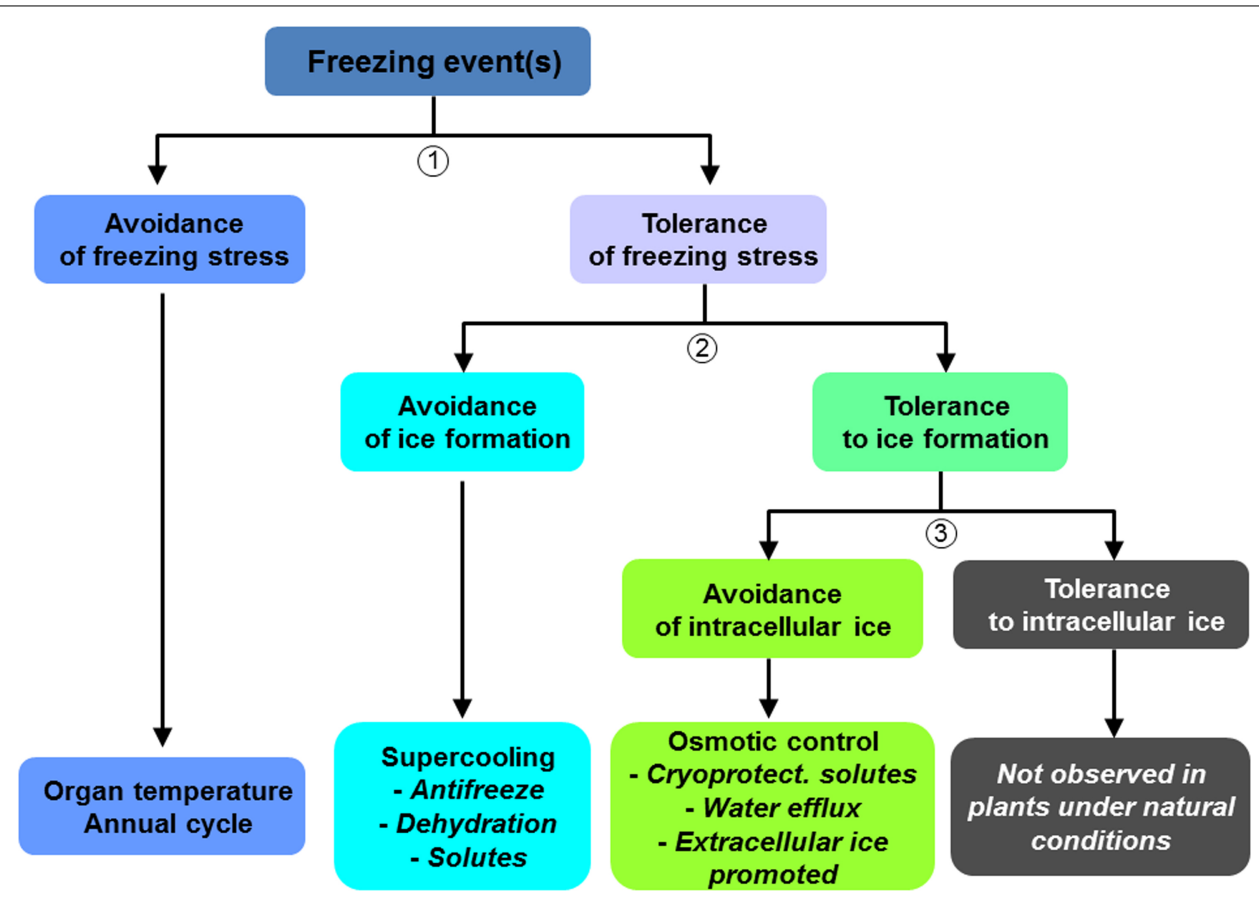

FIGURE 1 | Strategies developed by trees to avoid or tolerate freezing stress and ice formation (adapted from Levitt, 1980).

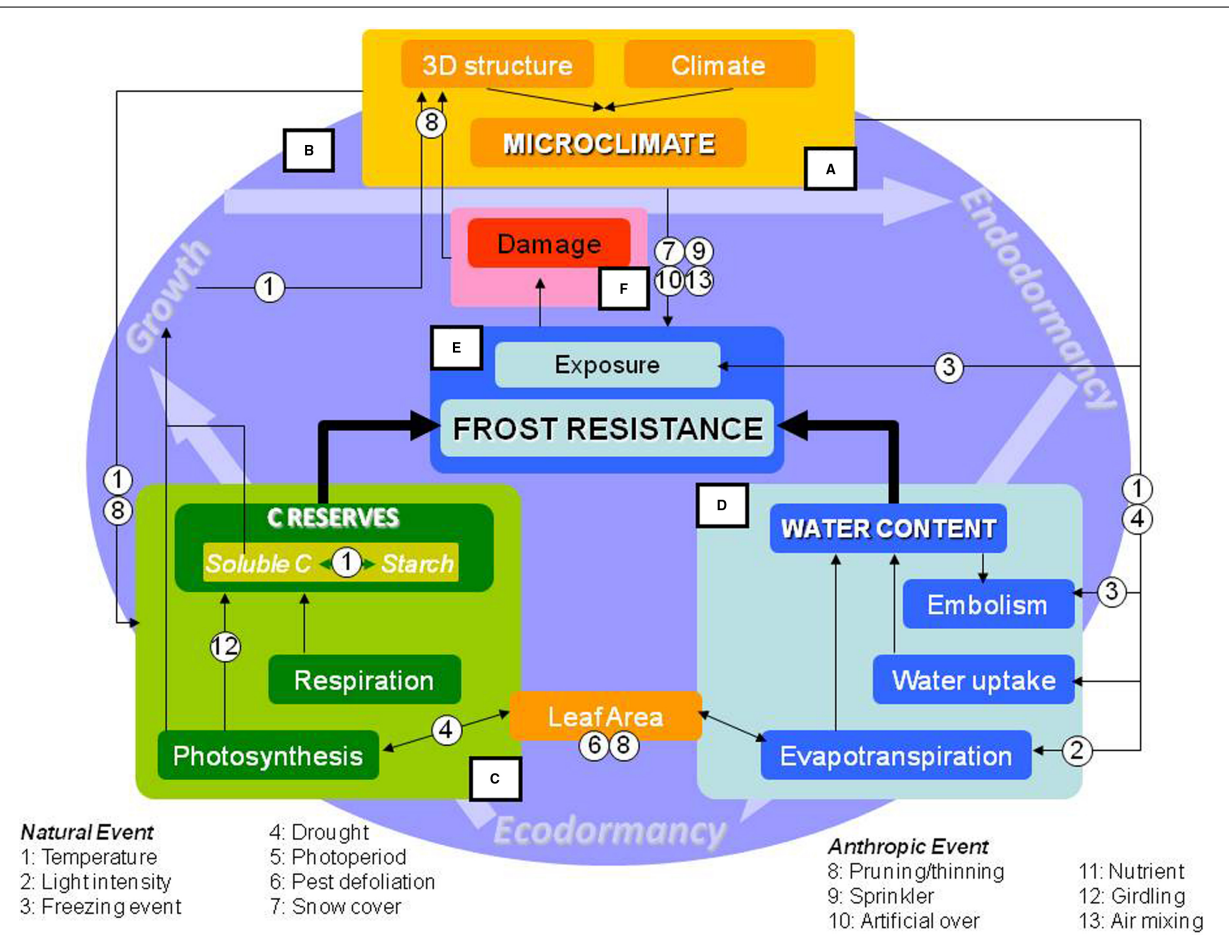

FIGURE 2 | Conceptual framework of processes involved in frost resistance development in trees. The microclimate (Frame A) results from interactions between the climate and spatial structure of tree canopies. Trees experiencing freezing events integrate ecophysiological and internal processes throughout the entire year (Frame B). Among these biophysical factors, the balance of total non-structural carbohydrates (e.g., sugars and starch reserves; Frame C) results from various source-sink interactions during the year. Water content (Frame D), is regulated by input-output fluxes, which may lead to embolism. Non-structural carbohydrates, water content, and previous year damage affect frost resistance (Frame E) and survival (Frame F). These interactions are modulated by either natural events (numbered 1-7) or anthropogenic events (numbered 8-13). 


\section{Symptoms of Low Temperature Damage}

Low temperatures affect living plant cells and non-living lignified structures. Depending on whether the temperature falls below the freezing point of the sap, chilling or freezing damage occurs (Sakai and Larcher, 1987). Freezing damage also depends on the location of ice formation.

\section{Chilling Damage}

Chilling stress, which is common in tropical species, causes (i) limited exchanges among cells due to decreased membrane fluidity and decreased activities of membrane-bound pump channels (Alves et al., 2001), (ii) decreased metabolism through decreased enzymatic activity (Lyons and Raison, 1970), (iii) protein denaturation (Siddiqui and Cavicchioli, 2006), and (iv) differential gene expression. For a review of these mechanisms, see Ruelland et al. (2009). During the leafy period, low temperatures affect the activity of photosynthetic-related enzymes. Therefore, electrons accumulate in the photosystems and generate reactive oxygen species (Ensminger et al., 2006; Mai et al., 2009; Silva-Cancino et al., 2012).

\section{Frost Damage to Living Cells}

When temperatures drop below $0^{\circ} \mathrm{C}$, water may crystallize around a nucleus, typically in the extracellular compartment (Figure 1). Latent heat released by the crystallization of extracellular (i.e., apoplastic) water can be detected as a high temperature exotherm (HTE). HTEs, recorded between -2 and $-4^{\circ} \mathrm{C}$, display no seasonal pattern (Pramsohler and Neuner, 2013). Tissues exhibiting secondary growth are usually tolerant to extracellular freezing, but the chemical potential of ice draws water from the intracellular to the extracellular compartment, causing cell dehydration and shrinkage (Dowgert and Steponkus, 1984). As the freezing point is lowered, cells may be able to supercool $\left(<-10^{\circ} \mathrm{C}\right)$, or in some species, deep-supercool $\left(<-40^{\circ} \mathrm{C}\right)$, leading to a "vitrified" cytoplasm (Wolfe and Bryant, 2001).

Whenever intracellular ice is formed, an exotherm is generated at a lower temperature than that of extracellular ice formation. Low temperature exotherms differ among species (e.g., in relation to their origin; Burke et al., 1976; Kaku and Iwaya, 1979) and among seasons (Pramsohler and Neuner, 2013). Intracellular ice results in a low water potential at the ice-water interface, which interferes with molecular bonds (hydrogen, van der Waals, and hydrophobic bonds), leading to membrane disruption and denaturation of macromolecules such as enzymes and structural proteins (Uemura et al., 2006; Ruelland et al., 2009). Under natural conditions, intracellular ice formation usually causes cell death (Wolfe and Bryant, 2001; Gusta et al., 2004; Muldrew et al., 2004).

\section{Frost Damage to Lignified Structures}

Extracellular ice causes mechanical strain on cell walls, leading to collapse and osmotic disturbances in cells with macromolecule and membrane denaturation (Steponkus, 1981). This effect, combined with an increased volume of extracellular ice (ca. $10 \%)$, can generate frost cracks in wood (Ishida, 1963; Cinotti,
1991). Damage may also result from the biomechanical effects of freezing (Charrier et al., 2014a). Frozen sap increases wood stiffness (i.e., higher Young's modulus, E), which helps crowns bear the weight of snow and ice, up to their breaking point (Umbanhowar et al., 2008). Successive freezing and thawing of apoplastic water generates water fluxes (Améglio and Cruiziat, 1992; Améglio et al., 2001). Air bubbles expelled from ice can dilate during thawing, inducing xylem embolism (Améglio et al., 1995; Lemoine et al., 1999; Hacke and Sperry, 2001; Améglio et al., 2002; Charrier et al., 2014b; Kasuga et al., 2015). A major determinant of xylem sensitivity is the diameter of the conducting elements (Davis et al., 1999; Pittermann and Sperry, 2003; Charrier et al., 2014b). After a single freeze-thaw event, embolism resulted in a $100 \%$ loss of hydraulic conductivity in Quercus robur, compared to 0\% in Pinus sylvestris (Charrier et al., 2013a), However, species with narrow xylem-conducting elements can also develop embolism after many successive freeze-thaw cycles (Mayr et al., 2006, 2007). Low temperatures significantly affect the loss of hydraulic conductivity, but only in wider xylem conduits (Mayr and Sperry, 2010; Charrier et al., 2014b). Among poplar clones, trees with narrow xylem vessels were more resistant to freezing-induced embolism and grew more vigorously (Schreiber et al., 2013). Consequently, winter embolism is a major factor controlling the locations of treelines (Mayr et al., 2002, 2003, 2014; Charrier et al., 2013a). Successive freezing and thawing can also affect subsequent drought resistance in apple trees, a phenomenon known as "frost fatigue" (Christensen-Dalsgaard and Tyree, 2013, 2014).

\section{Modulation of Frost Resistance}

Frost resistance exhibits significant spatio-temporal phenotypic plasticity. To sustain freezing temperatures, trees are able to transiently increase their frost resistance (i.e., acclimate) from a few degrees below $0^{\circ} \mathrm{C}$ to temperatures as low as liquid nitrogen $\left(-196^{\circ} \mathrm{C}\right.$; Sakai and Larcher, 1987). Contrasting behaviors are also observed across organs (Charrier et al., 2013b).

\section{Temporal Patterns of Frost Resistance}

\section{Autumn}

In autumn, frost acclimation is associated with growth cessation and endodormancy development (Weiser, 1970; Hänninen and Kramer, 2007; Kalcsits et al., 2009). Decreasing photoperiod and cold temperatures induce budset, growth cessation, and frost acclimation (Aronsson, 1975; Christersson, 1978; Arora and Rowland, 2011; Pagter and Williams, 2011). Frost resistance can be modeled using two independent responses, one to short photoperiods, and the other to cold temperatures (Leinonen, 1996). Similarly, two independent pathways may govern endodormancy release: one regulated by photoperiod (enhanced by warm temperatures) and the other regulated by cold temperatures (Tanino et al., 2010).

The rate of cold acclimation is related to temperature (Greer and Warrington, 1982). After a long warm autumn, a single freeze event can significantly damage apical buds and cause tree mortality (Fady et al., 2003). However, an artificially elevated temperature combined with a short photoperiod can induce 
significant acclimation (Schwarz, 1970; Charrier and Améglio, 2011). In that study, the authors hypothesized that low $\left(<5^{\circ} \mathrm{C}\right)$ and warm $\left(>15^{\circ} \mathrm{C}\right)$, but not mild temperatures, induced frost resistance because higher enzymatic activity enhanced starch hydrolysis, producing more cryoprotectant solutes (Sakai, 1966; Elle and Sauter, 2000). Cold hardening can be inhibited by an artificial increase in the water content of the tissues (Charrier and Améglio, 2011), which is efficient for low levels of frost resistance (cf. see Strategies Driving Frost Resistance). Therefore, warm soil temperatures decrease frost resistance by maintaining root system activity (Frames A, D, and E, Figure 2).

\section{Winter}

In deep winter, the main frost risk comes from winter drought rather than frost injury, especially at high altitudes or latitudes (Mayr et al., 2003; Man et al., 2013). When soil is frozen, dehydration of aboveground parts is not compensated by water uptake from the roots, which can be lethal to sempervirent plants (Tranquillini, 1979). In very cold areas, plants may be totally encased in ice and damaged from anoxia. Frost risks are maximal at the colder edges of plant altitudinal and latitudinal distributions (Charrier et al., 2013a). Mild spells that induce deacclimation (Kalberer et al., 2006; Pagter et al., 2011) can be damaging when frost resumes (Saarinen et al., 2011).

\section{Spring}

In temperate zones, spring frost risks are more abundantly documented than those for other periods. Critical damage to flowers or buds can ruin a year's harvest (Rodrigo, 2000). In the context of climate change, many studies have focused on forecasting frost risk, but these analyses have yielded conflicting results. Frost risk is predicted to increase (Hanninen, 1991; Inouye, 2008; Augspurger, 2013) or decrease (Murray et al., 1989; Scheifinger et al., 2003; Eccel et al., 2009; Baraer et al., 2010; Bennie et al., 2010; Dai et al., 2013). A mean temperature increase, with constant variance, would be expected to lower frost exposure, even though the sensitive stages of plant development occur earlier in the spring. Nevertheless, some authors highlight a complex pattern (Linkosalo et al., 2000, 2006; Rochette et al., 2004; Gu et al., 2008), with antagonistic effects of increasing temperatures and temperature variability (Rigby and Porporato, 2008). An increase in both the mean and variance (predicted by IPCC; Field et al., 2014) implies that freezing events could still occur and damage flushing buds. In most cases, the safety margin between damaging temperatures and frost resistance (ca. $5^{\circ} \mathrm{C}$ ) should prevent damage (Lenz et al., 2013). However, spring damage to flowers occurs more often at the cold margins of plant distributions (Cittadini et al., 2006). Late budburst may prevent spring frost damage. However, late frost damage might have strong consequences for elongating stems and developing leaves, such as poor recovery of photosynthesis, shorter growing seasons, and less production of non-structural carbohydrates (NSC; Ball et al., 1997).

\section{Summer}

In summer, plants are especially vulnerable, but freezing events occur only at the edges of the ecological distributions: at high altitudes (Larcher et al., 2010; Pramsohler et al., 2012; Ladinig et al., 2013; Neuner et al., 2013) and high latitudes (Christersson, 1971; Burke et al., 1976; Gorsuch and Oberhauer, 2002). In summer, frost damages only the most vulnerable and exposed organs (fruits, flowers, and buds; Hacker et al., 2011).

\section{Ontogenetic Effect}

Many factors can affect frost resistance, including plant height, microclimate, and soil conditions, but these are not easy to study independently. Hence, only a few studies have focused on the effect of age on frost resistance. However, seedlings and saplings are generally more sensitive than are adults. For example, significant year-to-year increases in frost resistance are observed in juvenile Rhododendron spp, but not in adults (Lim et al., 2014).

\section{Spatial Distribution of Frost Resistance}

Spatial heterogeneity in frost resistance is observed across organs and tissues (Sakai and Larcher, 1987). Differential distribution of frost resistance is both qualitative (extracellular freezing or supercooling) and quantitative (acclimation). Long-term survival of plants is tied to meristem protection. Bud development is important for primary vegetative growth and reproduction, whereas cambial development is important for secondary growth. Differences in frost resistance among organs have been described in detail for only a few species: e.g., the liana, Hedera helix (Andergassen and Bauer, 2002), the forest trees, Abies alba and Acer pseudoplatanus (Larcher and Mair, 1968; Larcher, 1985), and the fruit tree, Juglans regia (Charrier et al., 2013b).

The root system survives only moderate extracellular freezing (ca. -5 to $-10^{\circ} \mathrm{C}$; Stattin et al., 2012), and, except for the tap root, does not exhibit a seasonal pattern (Charrier et al., 2013b). Fine roots are the most sensitive (ca. $\left.-5^{\circ} \mathrm{C}\right)$, and can be severely damaged under bare soil (Cleavitt et al., 2008). During winter, snow cover protects roots by keeping soil temperatures above freezing (Comerford et al., 2013). The trunk is the most resistant part because it is usually protected by thick bark that has a high thermal inertia (Moran et al., 2011). However, mechanical damage can be observed on trunks in autumn when they are fully hydrated. The expansion of water (sap) during freezing can cause mechanical strain to exceed cell wall rigidity and cause frost cracks (Ishida, 1963; Cinotti, 1991).

Of the different plant tissues, bark is the most resistant, much more so than wood (Arora and Wisniewski, 1994; Charrier et al., 2013b). Buds are probably the most sensitive and most frost-exposed organs (Ashworth et al., 1985; Pramsohler et al., 2012). Many studies have focused on the deep supercooling ability of plants and ice propagation in buds and wood (Itier et al., 1991; Jones et al., 2000; Hacker et al., 2011; Kuprian et al., 2014; Charrier et al., 2015). In winter, the buds are disconnected from the wood xylem, which may prevent ice from propagating into the bud (Hacker et al., 2011). In spring, the barrier between xylem and buds is removed, and ice propagation into the bud may cause severe damage (Pramsohler and Neuner, 2013), jeopardizing the entire year's fruit production (Rodrigo, 2000; Rowland et al., 2013).

Inside the vegetative bud, the leaf primordia are the most sensitive parts, whereas procambium and pith parenchyma can survive 
lower temperatures (Andergassen and Bauer, 2002). In flowers, freezing stress on the pistil and ovules determines the potential survival of the seeds produced (Lardon and Triboi-Blondel, 1994). Buds in the lower part of the tree are more frost-vulnerable than those higher up (Read, 1967). Buds facing the sun are more resistant than those at the opposite side (Read, 1967).

\section{Strategies Driving Frost Resistance}

As observed for most stresses (biotic or abiotic; Grime, 1977), tree frost resistance involves two main strategies: avoidance and tolerance (Levitt, 1980; Figure 1).

\section{Avoidance of Freezing}

A stress avoidance strategy is exhibited by some species-the spatial and temporal distribution of sensitive organs and meristems provides protection from cold temperatures. Raunkiaer (1934) proposed a classification of plants according to the position of meristems during the dormant season. Meristems located belowground (e.g., Cryptophytes) or under cover (e.g., Chamaephytes) have less exposure to cold temperatures than do meristems above the snow cover (e.g., Phanerophytes). For temperate and boreal species, these adaptations allow freezing events to be avoided. At a larger scale, stress avoidance can be illustrated by the biogeographical distribution of a given species, reflecting adaptation to abiotic and biotic stresses. Dyschronism between sensitive phenological stages and freezing events is an avoidance strategy (e.g., leaf fall for deciduous species). Stress avoidance is, therefore, related to freezing temperature exposure, from the global to the microclimatic scale.

\section{Tolerance to Freezing}

As stated above, damage to plant tissues depends on the quantity, location, and rate of ice formation (Figure 1). However, plants are able to partially control ice formation, lessening frost risk. Ice formation can be avoided by the production of antinucleators such as anti-freeze proteins (Pearce, 2001; Figure 1), which allow supercooling of the sap. Ice barriers can block ice propagation within sensitive tissues at different times (e.g., protection of buds in winter; Dereuddre and Gazeau, 1992; Pramsohler et al., 2012).

Other resistance mechanisms involve the inhibition of intracellular ice formation (Figure 1). Increased intracellular osmotic potential (mediated by solutes or aquaporins) is a strategy shared by different crop genera such as Juglans (Améglio et al., 2004; Charrier et al., 2013b), Malus (Pramsohler and Neuner, 2013), Quercus, Fagus, and Betula (Morin et al., 2007; Charrier et al., 2013a). Osmotic control maintains or stabilizes intracellular structures through the use of low molecular weight molecules such as mono- and oligosaccharides, polyols, amino acids, lipids, and macromolecules such as dehydrins (Yoshida, 1984; Khanizadeh et al., 1992; Arora and Wisniewski, 1996; Arora et al., 1997, 2004). An increase in cell wall thickness and stiffness to cope with mechanical strains, and a decrease in the degree of saturation of fatty acids to maintain membrane fluidity at low temperatures are also observed (Yoshida and Uemura, 1986; Uemura and Steponkus, 1994). Cryoprotectant molecules help cells withstand dehydration by excluding water from sensitive areas. Aquaporin expression significantly increases frost resistance by increasing cell membrane permeability (Peng et al., 2008a,b). In extreme cell dehydration, the remaining water is tightly bound to cell structures in a "vitrified state" (Wolfe and Bryant, 2001). Membrane stabilization during freezeinduced contraction and thaw-induced expansion is a key process in cell survival (Uemura et al., 2006). The rate of temperature change is, therefore, critical because plant cells may or may not have time for water to cross the plasma membrane.

Soluble carbohydrates, are involved in frost resistance of living cells and the refilling of water conduits, and can account for the ecological distributions of trees (Charra-Vaskou et al., 2012; Charrier et al., 2013a). Living cells are, thus, crucial for the maintenance of a functional hydraulic system. On the one hand, electrolyte leakage from damaged cells increases the tension in the apoplast near the vessels; this increases the vulnerability of vessels to embolism (Ball et al., 2006). On the other hand, vesselassociated cells are able to actively refill embolized vessels more easily by carbohydrate export (Améglio et al., 2001, 2002, 2004; Decourteix et al., 2006, 2008) and ATP-H ${ }^{+}$pump channel activity (Alves et al., 2001, 2004). Aquaporins may also be involved in the recovery of xylem from embolism, as demonstrated in Juglans regia (Sakr et al., 2003).

The physical behavior of water and its interaction with different cellular components control the formation of ice within the tissues. The probability of ice nucleation depends on the volume of the compartment, the presence of nucleation sites, and the concentration of the liquid sap. High concentrations of cryoprotectants (mostly carbohydrates), combined with less intracellular water to freeze, are key to surviving very cold temperatures. Using the contents of water and soluble carbohydrates as input variables, frost resistance was accurately predicted independently of age, organ, and tissue (Frames C-E, Figure 2; Charrier et al., 2013b). For example, along a branch, gradients in water and carbohydrates are observed (Table 1). However, frost resistance exhibited no corresponding differences, owing to the antagonistic effects of water and carbohydrates. A non-linear interaction between these two variables suggests that modulation of water content drives low levels of frost resistance, whereas soluble carbohydrates are responsible for the greatest levels of frost resistance $\left(<-20^{\circ} \mathrm{C}\right.$; Charrier et al., 2013b).

TABLE 1 | Frost hardiness, starch content, soluble carbohydrate content, and water content along a branch of walnut (length $>1 \mathrm{~m}$ ) in mid-autumn (October).

\begin{tabular}{|c|c|c|c|c|}
\hline & $\begin{array}{c}\text { Frost } \\
\text { Hardiness }\left({ }^{\circ} \mathrm{C}\right)\end{array}$ & $\begin{array}{c}\text { Starch } \\
\text { (mg.g } \\
-1 \text { DM) }\end{array}$ & $\begin{array}{c}\text { Soluble } \\
\text { carbohydrates } \\
\text { (mg.g }{ }^{-1} \text { DM) }\end{array}$ & $\begin{array}{c}\text { Water } \\
\text { content } \\
\text { (g.g }{ }^{-1} \text { DM) }\end{array}$ \\
\hline Apex & $-17.2 \pm 0.6^{a}$ & $76.4 \pm 1.4^{b}$ & $56.4 \pm 6.3^{b}$ & $1.17 \pm 0.05^{b}$ \\
\hline Middle & $-18.3 \pm 1.7^{a}$ & $50.6 \pm 6.5^{\mathrm{a}}$ & $42.2 \pm 9.6^{\mathrm{a}}$ & $0.98 \pm 0.04^{a}$ \\
\hline Base & $-17.6 \pm 0.7^{a}$ & $62.8 \pm 4.1^{a b}$ & $35.5 \pm 6.3^{a}$ & $0.88 \pm 0.04^{a}$ \\
\hline
\end{tabular}

Values are mean \pm standard error from $n=5$ replicates. For each variable, branch locations with the same letter are not significantly different according to ANOVA and the LSD criterion $(P<0.05)$. Results are from Charrier (2011). 


\section{Environmental Factors and Management Practices Influencing Frost Risk}

Environmental factors and management practices interact with physiological variables in complex ways during periods of vegetative growth and dormancy (Frame B, Figure 2). Frost damage, as defined and described in Part 2, occurs when high hazard and low resistance are concomitant (Frames A, E, and F, Figure 2). Hazard and frost resistance are modulated spatially and temporally at the tree scale, and can be severely impacted by management practices. In addition, environmental factors fluctuate independently. Multiple stresses can occur simultaneously or successively (Niinemets, 2010), affecting either resistance or hazard. However, moderate stress can also act as a warning signal ("stress priming"), inducing physiological changes and triggering acclimation to subsequent stresses.

As stated previously, low water contents and high concentrations of NSCs enhance frost resistance (Frames C-E, Figure 2). Thus, heterogeneity in frost resistance may lead to heterogeneity in NSC and water contents at the end of the growing season. Such spatial variability results from the concurrent interactions and feedback between the local microclimate and tree functioning.

\section{Air and Organ Temperatures Organ Temperature}

Air temperatures are influenced by microclimate, topography, and soil characteristics (Ball et al., 1997; Blennow, 1998; Blennow and Persson, 1998). Therefore, organ temperature is driven by the surrounding microclimate, but is also modulated by the organ's physiological state (Chelle, 2005). The within-crown microclimate is highly variable spatiotemporally, and changes according to plant architecture, structure of the surrounding vegetation, climate, and pedoclimate (Frame A, Figure 2). Thus, many factors influence organ temperature and subsequent hazards. These factors include crown characteristics (e.g., structure, size, geometry), organ characteristics (e.g., horizontal or erect orientation, height above the ground), soil properties (e.g., moisture content, color, presence of scarified ground or grass), weather conditions (e.g., wind speed, air temperature, and radiation), and the presence of cover (Leuning, 1988; Leuning and Cremer, 1988; Jordan and Smith, 1994; Ball et al., 1997; Blennow, 1998; Blennow and Persson, 1998; Mayr et al., 2006; Winkel et al., 2009). The dynamics of organ temperature have been less thoroughly studied than those of air temperature. The temperatures of leaves, fruits, and stems can be simulated by solving an energy balance equation (Sinoquet et al., 2001; Potter and Andresen, 2002; Saudreau et al., 2007), and the risk of freezing can be accurately estimated (Cellier, 1984, 1993; Leuning, 1988; Jordan and Smith, 1994).

\section{Air Temperatures During a Freezing Event}

Under natural conditions, two kinds of freezing events can be observed: advective frosts (intrusion of cold air) and radiative frosts (negative heat energy balance). Freezing events that damage plants are more often radiative than advective. For example, $90 \%$ of freezing events in Swedish mountainous areas are caused by radiative freezing (Lindkvist et al., 2000). Radiative frosts are comparable to dew formation: nighttime radiant cooling of an exposed organ lowers its temperature, and this may fall cause the freezing of water droplets on the organ's surface (Monteith and Unsworth, 1990). Radiative frosts typically occur after sunset when the sky is clear and wind speeds are low. When no solar radiation is entering the system, and long-wave infrared radiation is being dissipated to the sky, the heat energy balance becomes negative. With a negative energy balance, the temperature of the system (either the air layer around the plant or the plant itself) falls (Snyder and Melo-Abreu, 2005). This occurs more frequently in narrow valleys than in concave or flat locations, and less frequently in elevated and convex areas more exposed to wind (Lindkvist et al., 2000). Thus, high winds narrow the differences between the organ and air temperatures by reducing the thickness of the boundary layer (Jordan and Smith, 1994; Michaletz and Johnson, 2006). Air temperatures are lower than soil temperatures (Friedland et al., 2003), with the lowest air temperatures being close to the ground (Leuning and Cremer, 1988; Jordan and Smith, 1994; Blennow, 1998; Battany, 2012) or in the upper canopy (Winkel et al., 2009).

\section{Organ Temperatures During a Freezing Event}

Canopy structure can either decrease or increase the probability and intensity of freezing. This is modulated through the structural arrangement of foliage, including canopy height, length, density, porosity, and leaf area index (Landsberg and Thom, 1971; Grant, 1984; Winkel et al., 2009), and through individual organ characteristics such as size, geometry, and orientation of the leaf or bud. These factors significantly influence intra-crown air temperatures around the organs (Michaletz and Johnson, 2006) and the exposure of organs to wind and radiation (Wilson and Flesch, 1999; Kuhrt et al., 2006; Batzer et al., 2008; Saudreau et al., 2009). A dense tree canopy buffers sensitive tissues from adverse weather conditions, reducing the probability and intensity of freezing events (radiative or advective). Minimum leaf temperatures generally remain higher in dense stands than in open stands (Blennow, 1998; Kuhrt et al., 2006; Winkel et al., 2009) because a dense canopy impedes the upward dissipation of heat and reduces the cooling effects of wind (Nobel, 1974; Landsberg et al., 1975; Phillips et al., 1983; Hamer, 1985). Under canopies, daily differences in organ temperatures are lower, and soil and air moistures are higher (Chen et al., 1993; Carlson and Groot, 1997; Wilson and Flesch, 1999; Kuhrt et al., 2006). Conversely, more open canopies increase the loss of infrared radiation when skies are clear and winds are low (Wilson and Flesch, 1999; Batzer et al., 2008; Richard et al., 2013).

At the leaf scale, larger horizontal leaves lose heat faster and become colder than small erect leaves (Jordan and Smith, 1994). Also, horizontal leaves may bear water droplets that act as nucleating agents for ice formation (Wisniewski et al., 2002; Gusta et al., 2004). Therefore, leaf wettability is a critical factor that decreases across plant species along an altitudinal gradient (Aryal and Neuner, 2010). In leaves, ice propagates faster near the leaf tip and margins than at the petiole and midvein (Ball et al., 2002). Spatial patterns of ice formation can affect the distribution and extent of damage in autumn when the duration of freezing temperatures may be too short for the whole leaf to freeze before sunrise. 
The temperature of the shoot apical meristem may deviate from the air temperature by $\pm 4^{\circ} \mathrm{C}$ (Yamada and Takahashi, 2004). Phenological stage and surface wetness significantly influence the degree of supercooling that buds can undergo before freezing (Itier et al., 1993). Interspecific differences are observed depending on bud structure (e.g., thickness of the cuticle and thermal insulation provided by bristles), and these interact with environmental variables such as air temperature, vapor pressure deficit, radiation, and wind speed (Savvides et al., 2013).

Wide variability in temperature dynamics between plant parts that are exposed and unexposed to direct solar radiation has been observed on perennial woody parts such as stems or trunks (Derby and Gates, 1966; Potter and Andresen, 2002; Kuhrt et al., 2006; Mayr et al., 2006). Hence, the portions of the trunk and branches that face the sun and wind often experiences two times more freeze-thaw cycles with faster freezing and thawing compared to the other sides of the tree (Derby and Gates, 1966; Mayr et al., 2006).

\section{Artificial Modulation of Frost Exposure}

Artificial techniques can protect plants from radiative frosts. For instance, irrigation of plants by sprinkling them with cool water can prevent frost damage to flowers by delaying budburst (Lakatos et al., 2011). Wind machines have been used to prevent freezing by mixing air layers (Ribeiro et al., 2006). Upward facing wind machines are significantly more efficient (Battany, 2012). Using the exothermal heat of ice crystallization, water aspersion warms plant tissues by a few degrees, and this can prevent damage. By combining covers and sprinklers, organ temperatures can remain 2 to $10^{\circ} \mathrm{C}$ higher than air temperatures, even with temperatures as low as $-20^{\circ} \mathrm{C}$ (Cary, 1974). Soil irrigation increases heat transfer and storage. However, wet soils, which are darker than dry soils, can increase absorption of solar radiation. Artificial shelters are relatively efficient for reducing wind speeds, but inefficient for raising minimum temperatures under wet conditions (McAneney et al., 1990). Advective frosts can be minimized by limiting cold air intrusion. Sheltering and windbreaks reduce snow blowing, slightly increasing temperatures and reducing evaporation (see Brandle et al., 2004).

Removal of biomass via pruning, thinning, and girdling, or by defoliation, significantly impacts orchard and forest trees. "Pruning" usually means removing woody parts from the canopy, whereas "thinning" usually means removing either individual or clusters of fruits or flowers. In the short-term, modification of canopy structure impacts the microclimate by increasing the energy lost by long-wave radiation (Willaume et al., 2004; Stephan et al., 2008; Frame A, Figure 2). Although canopy modification may lower the minimum temperatures during freezing events, removing lower buds can also help avoid frost exposure on the remaining buds in the orchards. The remaining buds, flowers, and fruits are located higher in the tree where the temperatures are warmer. Pruning also indirectly enhances height growth by increasing light transmittance within the canopy (Usenik et al., 2008; Weber et al., 2011; Haouari et al., 2013). This decreases the probability of frost exposure to the newly formed apical buds. This effect can be observed when pruning removes more than $30 \%$ of total twig length (Fumey et al., 2011; Forrester, 2013).
In cold climates, deciduous trees should not be pruned during the dormant season. For example, see Snyder et al. (2005) for a review of problems that may occur when trees are pruned during dormancy. In grapevines, pruning in the dormant season may delay budburst and blooming, thereby reducing frost damage to the flowers (Friend et al., 2011) and delaying leaf fall (Weber et al., 2011). When defoliation breaks paradormancy, trees refoliate, exposing sensitive organs to early frosts and depleting their reserves (Wargo, 1972; Wargo et al., 1972). Following defoliation stress, budburst may occur earlier the subsequent spring, increasing frost risk (Carroll and Quiring, 2003).

\section{Carbon Balance}

Frost resistance during winter is related to the content of NSC (Palonen and Buszard, 1997). More particularly, maximum frost resistance is correlated with total NSC in the autumn (Morin et al., 2007; Poirier et al., 2010; Charrier et al., 2013a). Thus, autumnal NSC levels are a critical variable for the coming winter-it is an integrator of the carbon fluxes and the allocation that occurs during the previous growing season. Furthermore, it may be indirectly impacted by the factors influencing carbon assimilation, respiration, and allocation (Frame C, Figure 2). Among these factors, natural or artificial biomass disturbances affect the activity of the main source and sink organs. These source and sink organs include leaves, foliar and floral buds, growing fruits, and shoots. Their impact on frost resistance may be variable, and are detailed below.

\section{Winter NSC Dynamics}

Winter carbon balance, as measured by NSC dynamics, is mainly influenced by the respiration rate (Ögren, 2000). Respiration is temperature-dependent, and exhibits annual changes, such as variation in the basal respiration of leaves during the year (Wythers et al., 2005; Tjoelker et al., 2009). However, very few data are available for fruit tree species (Wibbe et al., 1994).

Warm autumn temperatures delay root dormancy. Root dormancy is not induced by short days and roots have no chilling requirement to resume growth (Coutts et al., 1990; Nicoll and Coutts, 1998). Therefore, mild winters may enhance respiratory losses, which accelerate the draw-down of carbohydrate reserves (Crawford and Palin, 1981). This may lead to increased mortality of roots and the aerial parts of the plant (Fitter et al., 1998, 1999). Concurrently, the dynamic equilibrium between starch and soluble carbohydrates varies with temperature. Starch is converted into soluble sugars by amylase at both low (Sauter and van Cleve, 1991; Witt and Sauter, 1994) and warm temperatures (Sakai, 1966). This explains why NSC contents are often related to frost resistance (Coleman et al., 1992; Palonen and Buszard, 1997; Wong et al., 2003, 2009; Turhan and Ergin, 2012; Ito et al., 2013). Also, starch hydrolysis and starch-derived sugar respiration are enhanced by warmer temperatures (e.g., temperatures above $15^{\circ} \mathrm{C}$ ). This leads to decreased starch reserves, but frost resistance may not be affected (Schwarz, 1970; Charrier and Améglio, 2011). Active transport of sugars is observed at cold, but not freezing temperatures, and sugar transport is probably involved in the resorption of air bubbles in embolized xylem (Améglio et al., 2004, 2005; Decourteix et al., 2008). 


\section{Modulation of Maximum NSC During the Growing Season}

In autumn, NSC content is driven by the tree carbon balance. That is, the total assimilated carbon allocated to growth (e.g., vegetative, flower, and fruit), reserve compounds (mostly starch distributed among the different tree parts), and respiration. Silpi et al. (2007) and other authors showed that NSC reserves formed an active sink, driving a large part of the assimilated carbon into NSC with a wide margin between reserves and structural carbohydrates (Sala et al., 2012). This contradicts the passive pool concept that is still included in many carbon-based models (Cannell and Dewar, 1994; Lacointe, 2000; Le Roux et al., 2001; Genard et al., 2008; Franklin et al., 2012).

Maximal NSC level is also influenced by the spatial heterogeneity of the tree crown and the translocation resulting from the activities of sinks and sources. Within canopies, the branch autonomy theory suggests that little carbon (and NSC) translocation occurs (Sprugel et al., 1991). This theory partially explains why branch growth and survival are affected by local light conditions and potential source/sink imbalances. The relative autonomy among shoots or branches was mostly observed in mature trees of various fruit species (Yamamoto et al., 1999; Volpe et al., 2008; Poirier et al., 2010). In addition, recent studies using whole-canopy stable isotope labeling showed rapid, seasonally variable allocation of recently assimilated carbon to belowground parts (see the review of Epron et al., 2012). These studies highlight the need to (i) enlarge the concept of sourcesink activity at the whole plant scale and (ii) integrate transport resistance mechanisms into plant models (Minchin and Lacointe, 2005).

The combination of spatial heterogeneity (resulting from tree geometry and source/sink balances) and sink activity of the NSC reserves leads to high variability in NSC location (Bory et al., 1991; Haddad et al., 1992). This inherent variability may affect winter frost resistance. Under limiting conditions (e.g., low temperatures), trade-offs between limited growth and allocation to NSC reserves should ensure sufficient frost resistance (Hoch and Koerner, 2009, 2012; Wiley et al., 2013).

\section{Artificial Modulation of Source-Sink Relationships}

Most studies on biomass removal have shown alterations in the source-sink relationships, but with different outcomes on carbon balance and frost resistance. Pruning influences NSC, especially starch content, and this impacts (i) the differentiation of bud meristems (Andales et al., 2006; Bangerth, 2006; Frame C, Figure 2) and (ii) dormancy induction and release (Frame B, Figure 2). By removing sinks (e.g., fruits and starches) and sources (e.g., leaves), pruning has a large effect on NSC. The effects of pruning depend greatly on the timing (summer vs. winter), although very few studies are available. Summer pruning may have no effect on NSC (Usenik et al., 2008), or may promote NSC in different aboveground organs (Den and Son, 2000; Demirtas et al., 2010). However, summer and winter pruning have positive synergistic effects on starch content the second year after treatment (Den and Son, 2000), especially after fruit harvest (Demirtas et al., 2010). Changes in pruning frequency result in modifications in
NSC distribution and seasonal patterns in ornamental species. With regular pruning (e.g., annual winter pruning), local starch concentrations doubled (Bory et al., 1991). However, with irregular pruning (e.g., every 2-3 winters) higher starch concentrations were observed at the bases of side branches (Clair-Maczulatjis and Bory, 1988; Haddad et al., 1992). Much more information is needed on NSC content in response to pruning, especially in different organs, and its implications for frost resistance of these organs.

Thinning of fruits or flowers aims to manipulate the carbon sink strength and, thus, the optimization of crop load and/or fruit quality (Gordon and Dejong, 2007; Haouari et al., 2013; MirásAvalos et al., 2013; Frame C, Figure 2). Fruit thinning seems to (i) stimulate shoot growth (Pretorius et al., 2004; Gordon and Dejong, 2007; Forrester et al., 2013) and (ii) inhibit net $\mathrm{CO}_{2}$ assimilation by end-product inhibition (Francesconi et al., 1996; Wünsche et al., 2005; Haouari et al., 2013). Between these two contrasting possibilities, we hypothesize about the central role of NSC. Fruit removal may allow NSC resources to be allocated to the remaining fruits, or to other active sinks such as growing tissues. Haouari et al. (2013) found increased starch content in leaves and soluble sugars in fruits after $75 \%$ fruit thinning. Thus, thinning may compensate for lowered NSC content after drought stress (Lopez et al., 2007; Mirás-Avalos et al., 2013). Ultimately, thinning may influence the role of NSC in winter frost resistance.

Girdling, which is the partial or total removal of a ring of phloem around the bole, stops the basipetal movement of assimilates through the phloem, resulting in carbohydrate accumulation above the girdle (Mataa et al., 1998; Urban et al., 2004; Frame C, Figure 2). This practice is used to manipulate (i) tree growth and development and (ii) fruit growth, load, quality, and maturation in fruit species (Krezdorn, 1960; Barry and Veldman, 1997; Goren et al., 2004; McQueen et al., 2004; Pretorius et al., 2004; Urban et al., 2004; Boyd and Barnett, 2011). Girdled branches exhibit lower water contents, higher soluble carbohydrates, and more vigorous growth (Manoury-Danger et al., 2010; Poirier et al., 2010). Therefore, the shoots produced are more frost-resistant (Poirier et al., 2010). Below the girdled area, plants deplete their reserves for frost protection (Regier et al., 2010).

Abiotic and biotic stresses alter the processes described above. In their review, Sala et al. (2012) indicated that the negative effects of drought on carbon balance do not occur until the carbon reserves have begun to decline. This is especially pronounced when tree responses to drought are less limited by carbon availability than by accessibility and transport. Consequently, summer drought can significantly alter the levels of reserves, which may affect frost resistance the following winter (Poirier et al., 2010; Galvez et al., 2013). Very strong drought may lead to partial or total defoliation, limiting carbon acquisition. The consequences of defoliation by drought or pests appear to depend on the intensity of defoliation. When defoliation is moderate, carbon allocation to reserves can still be observed (Wiley et al., 2013). When defoliation is strong (e.g., loss of all leaves), NSC reserves are depleted (Poyatos et al., 2013; Rosas et al., 2013; Wiley et al., 2013). Plants with high levels of NSC are more likely to survive phytophagous defoliation (Wargo, 1979; Canham et al., 1999). Total defoliation late in the growing season (i.e., after growth cessation), does not 
significantly affect carbon balance (Morin et al., 2007; Poirier et al., 2010), but may strongly affect water balance, and this may disturb the first stage of cold acclimation (Charrier and Améglio, 2011).

\section{Water Balance}

Water balance is altered during the winter. Water uptake is limited by the decrease in root cell membrane fluidity caused by low soil temperatures (Wan et al., 2001; Lee et al., 2012). Artificially warmed soils $\left(>8^{\circ} \mathrm{C}\right)$ have greater root activity, leading to rehydration of aboveground organs (Charrier and Améglio, 2011). Under normal conditions, aboveground parts evaporate water through the bark. Up to half of the water content may evaporate in mid-winter (Charrier et al., 2013b). The amount of evaporated water depends on the thickness of the bark, on the microclimate (evapotranspiration ETP), and on the ratio of canopy volume to surface area. Therefore, microclimatic conditions can influence within-crown water content. Accurate prediction of water stored in the bark is possible using soil water potential and vapor pressure deficit as input variables (Zweifel et al., 2005). Under extreme conditions (e.g., frozen soils), substantial embolism can occur in the xylem, and this may result in winter drought (Mayr and Charra-Vaskou, 2007; Mayr et al., 2014).

Water availability affects plant physiology by altering the heat energy balance (Monteith, 1972), carbon balance (via stomatal closure), phenology (especially during cell expansion), and water status of plants (e.g., xylem embolism). Therefore, both drought and flooding can affect frost resistance (Frame D, Figure 2).

Although water excess and deficit have a direct effect on microclimatic conditions, it is unclear whether they affect phenology and the length of the growing season. Droughts are exacerbated by warm temperatures. However, using rain exclusion, Swidrak et al. (2013) observed that water availability had only a minor impact on the onset of growth in aboveground organs. Although locally stored water is preferentially used, drought may cause premature growth cessation. However, delayed budburst in waterlimited environments may decrease the overall water demand, allowing trees to have a longer growing season (Linares et al., 2012).

Flooding is mostly observed during the dormant season from autumn to spring. With flooding, temperatures decline, but are maintained above the freezing point. Whereas aboveground parts are relatively unaffected, roots may experience hypoxia (and in extreme cases anoxia), low nutrient availability, and low soil temperatures (van Cleve et al., 1981; Lieffers and Rothwell, 1986). Fine roots are sensitive to prolonged flooding, and growth is reduced when oxygen concentrations drop below $2.0 \mathrm{ppm}$ (Zinkan et al., 1974). Damaged roots exhibit reduced hydraulic conductivity, which can increase water stress and xylem injury in the subsequent summer (Lamhamedi and Bernier, 1994). Flooded roots also exhibit carbohydrate depletion, making them more vulnerable to post-anoxic injuries when water levels drop again in spring (Smith, 1994; Crawford, 1997, 2000). Therefore, successive flooding can deplete carbohydrate reserves, increase root mortality, increase drought stress, reduce anchorage, and lower resistance to wind.
Genes involved in the modulation of frost resistance are linked to dehydration-related genes (Swindell, 2006). In the short term, artificial dehydration and drought stress affect water balance and increase frost resistance (Li and Weiser, 1971; Medeiros and Pockman, 2010). However, stomatal closure has a marked effect on carbon balance (Lopez et al., 2007). The width of the safety margin between the water potentials that lead to growth cessation (limiting sink force) and those that lead to stomatal closure and cessation of photosynthesis is, consequently, a critical factor that controls the levels of carbon reserves at the end of the growing season (Mitchell et al., 2014). Frost resistance during the subsequent winter is also affected by extreme summer drought and summer warming (Kreyling et al., 2012, 2014). Prediction of forest tree dieback is related to frost risk. For example, frost may damage roots when the durations of snow cover are shortened, and this is exacerbated by summer drought (Auclair et al., 2010).

\section{Nutrients}

Nutrients have complex effects depending on which nutrient is being supplied and when. The relationship between specific nutrients and frost resistance is unclear. Fertilization generally increases growth by increasing leaf area, light interception, and transpiration. Therefore, carbon allocation is shifted to the aboveground plant parts, but the NSC pool is reduced, leaf coloration is delayed, and budburst is advanced (Thomas and Ahlers, 1999; Nikula et al., 2011; Forrester, 2013). In droughty soils, nutrients exhibit less mobility and assimilation, and this may lead to nutrient deficiency (Chapin, 1991).

Local increases in soil nitrogen induce root proliferation in these patches. The shape of the leaves directly connected to these patches by the xylem vessels may be affected in Acer spp, but not in Betula spp (Gloser et al., 2007). This heterogeneity may subsequently affect carbon assimilation under heterogeneous light, but probably only when soil water is limiting (Thorn and Orians, 2011).

Fertilized trees are more vulnerable to frost damage, especially the meristems. Application of nitrogen fertilizer in late summer or early autumn decreases frost resistance (Thomas and Blank, 1996). High nitrogen content affects potential defoliation (Albrectsen et al., 2004) and timing of frost hardening (Nikula et al., 2011). However, nitrogen is critical for root system activity and for inducing root pressures that help the resorption of air bubbles and alleviation of embolism (Ewers et al., 2001; Gloser et al., 2007; Thitithanakul et al., 2012). Phosphorus, which is involved in cell division, is important for recovery of tissues after freezing damage. Potassium has a favorable effect on water regulation and photosynthesis in plants, but its effect on frost protection is unclear (Snyder et al., 2005). Further research is needed, especially on the potential interactions between different nutrients and frost resistance.

\section{Conclusion and Perspectives}

The review of the different temporal and spatial patterns of frost resistance highlights two main points. First, frost damage may develop in living cells or hydraulic conducting systems with potential feedback between different levels. For example, 
living cells actively refill hydraulic conducting elements. Second, factors affecting exposure to low temperature, carbohydrate content, and water status are involved in frost risk. We propose that these latter factors form a foundation of an ecophysiologicallybased framework of frost risk assessment. Furthermore, microclimatic conditions may modulate carbon balance, water status, phenology, and temperature itself.

According to this framework, frost resistance results from variations in carbon and water balance that occur at various time scales. Changes in carbon and water balance result from changes in microclimate during the growing season, and from management practices. Therefore, the probability of frost damage increases when resistance is low and the probability of frost exposure is high. For example, under current climatic conditions, frost risks are greatest for buds in autumn or spring, and for stems in autumn when acclimation is delayed.

The development of this framework, which describes how frost resistance is affected by environmental factors and management practices, is an important step to assess frost risk in current and forecasted future climates. Understanding the physiological processes driving frost resistance will provide more robust predictions than simply understanding the empirical relationships between environmental conditions and frost risk. However, many aspects are still unclear, especially regarding the potential interactions

\section{References}

Albrectsen, B. R., Gardfjell, H., Orians, C. M., Murray, B., and Fritz, R. S. (2004). Slugs, willow seedlings and nutrient fertilization: intrinsic vigor inversely affects palatability. Oikos 105, 268-278. doi: 10.1111/j.0030-1299.2004. 12892.x

Alves, G., Améglio, T., Guilliot, A., Fleurat-Lessard, P., Lacointe, A., Sakr, S., et al. (2004). Winter variation of xylem sap $\mathrm{pH}$ in walnut trees: involvement of plasma membrane $\mathrm{H}^{+}$-ATPase of vessel-associated cells. Tree Physiol. 24, 99-105. doi: 10.1093/treephys/24.1.99

Alves, G., Sauter, J. J., Julien, J. L., Fleurat-Lessard, P., Améglio, T., Guilliot, A., et al. (2001). Plasma membrane $\mathrm{H}^{+}{ }_{-}$ATPase, succinate and isocitrate dehydrogenases activities of vessel-associated cells in walnut trees. J. Plant Physiol. 158, 1263-1271. doi: 10.1078/0176-1617-00503

Améglio, T., Alves, G., Decourteix, M., Poirier, M., Bonhomme, M., Guilliot, A., et al. (2005). Winter biology in walnut tree: freezing tolerance by cold acclimation and embolism repair. Acta Hortic. 705, 241-249.

Améglio, T., Bodet, C., Lacointe, A., and Cochard, H. (2002). Winter embolism, mechanisms of xylem hydraulic conductivity recovery and springtime growth patterns in walnut and peach trees. Tree Physiol. 22, 1211-1220. doi: 10.1093/treephys/22.17.1211

Améglio, T., and Cruiziat, P. (1992). Tension/pressure alternation in walnut xylem sap during winter: the role of winter temperature. C. R. Acad. Sci. III 315, $429-435$.

Améglio, T., Cochard, H., and Ewers, F. W. (2001). Stem diameter variations and cold hardiness in walnut trees. J. Exp. Bot. 52, 2135-2142. doi: 10.1093/jexbot/52.364.2135

Améglio, T., Cruiziat, P., and Béraud, S. (1995). Tension/pressure alter-nation in walnut xylem sap during winter: effect on hydraulic conductivity of twigs. C. $R$. Acad. Sci. III 318, 351-357.

Améglio, T., Decourteix, M., Alves, G., Valentin, V., Sakr, S., Julien, J. L., et al. (2004). Temperature effects on xylem sap osmolarity in walnut trees: evidence for a vitalistic model of winter embolism repair. Tree Physiol. 24, 785-793. doi: 10.1093/treephys/24.7.785

Andales, A., Wang, J., Sammis, T. W., Mexal, J. G., Simmons, L. J., Miller, D. R., et al. (2006). A model of pecan tree growth for the management of pruning and irrigation. Agric. Water Manage. 84, 77-88. doi: 10.1016/j.agwat.2006. 02.012 between the environment and physiology. Sublethal stresses may not cause mortality by themselves, but successive stressing events may progressively weaken the trees by decreasing NSC content, and this may improve the reproductive success of the most stress resistant individuals. This conceptual framework opens up new directions for further research on a pluri-annual timescale, which could be broadened to cover different species, genotypes, and locations.

\section{Author Contributions}

GC did the drafting, with input from the other three authors.

\section{Acknowledgments}

The authors thank Heikki Hänninen for inviting them to participate in the "Seasonality of woody plants in cold climates: adaptations, regulation and modeling" research topic, and Glenn Howe and two reviewers for their helpful comments and critical readings on the initial version of the manuscript. We are also grateful to the Austrian Science Fund (FWF) for funding the publication fees within the project I826-B25 "Acoufreeze" funded by Austrian (FWF) and French (ANR) research agencies.

Andergassen, S., and Bauer, H. (2002). Frost hardiness in the juvenile and adult life phase of ivy (Hedera helix L.). Plant Ecol. 161, 207-213. doi: 10.1023/A:1020365422879

Aronsson, A. (1975). Influence of photo- and thermoperiod on the initial stages of frost hardening and dehardening of phytotron-grown seedlings of scots pine (Pinus sylvestris L.) and Norway spruce (Picea abies L. Karst.). Stud. For. Suec. $128,20$.

Arora, R., and Rowland, L. J. (2011). Physiological research on winter-hardiness: deacclimation resistance, reacclimation ability, photoprotection strategies, and a cold acclimation protocol design. HortScience 46, 1070-1078.

Arora, R., Rowland, L. J., Ogden, E. L., Dhanaraj, A. L., Marian, C. O., Ehlenfeldt, M. K., et al. (2004). Dehardening kinetics, bud development, and dehydrin metabolism in blueberry cultivars during deacclimation at constant, warm temperatures. J. Am. Soc. Hortic. Sci. 129, 667-674.

Arora, R., and Wisniewski, M. (1994). Cold acclimation in genetically related (Sibling) deciduous and evergreen peach (Prunus persica L Batsch). 2. A 60kiloDalton bark protein in cold-acclimated tissues of peach is heat-stable and related to the dehydrin family of proteins. Plant Physiol. 105, 95-101. doi: 10.1104/pp.105.1.95

Arora, R., and Wisniewski, M. (1996). Accumulation of a $60-\mathrm{kD}$ dehydrin protein in peach xylem tissues and its relationship to cold acclimation. HortScience 31, 923-925.

Arora, R., Rowland, L. J., and Panta, G. R. (1997). Chill-responsive dehydrins in blueberry: are they associated with cold hardiness or dormancy transitions? Physiol. Plant. 101, 8-16. doi: 10.1111/j.1399-3054.1997.tb01813.x

Aryal, B., and Neuner, G. (2010). Leaf wettability decreases along an extreme altitudinal gradient. Oecologia 162, 1-9. doi: 10.1007/s00442-009-1437-3

Ashworth, E. N., Anderson, J. A., Davis, G. A., and Lightner, G. W. (1985). Ice formation in Prunus persica under field conditions. J. Am. Soc. Hortic. Sci. 110, 322-324.

Attaway, J. A. (1997). A History of Florida Citrus Freezes. Lake Alfred, FL: Florida Science Source, Inc.

Auclair, A. N. D., Heilman, W. E., and Brinkman, B. (2010). Predicting forest dieback in Maine, USA: a simple model based on soil frost and drought. Can. J. For. Res. 40, 687-702. doi: 10.1139/X10-023

Augspurger, C. K. (2013). Reconstructing patterns of temperature, phenology, and frost damage over 124 years: spring damage risk is increasing. Ecology 94, 41-50. doi: $10.1890 / 12-0200.1$ 
Balandier, P., Gendraud, M., Rageau, R., Bonhomme, M., Richard, J. P., and Parisot, E. (1993). Bud break delay on single node cuttings and bud capacity for nucleotide accumulation as parameters for endo- and paradormancy in peach trees in a tropical climate. Sci. Hortic. 55, 249-261. doi: 10.1016/03044238(93)90036-P

Ball, M. C., Canny, M. J., Huang, C. X., Egerton, J. J. G., and Wolfe, J. (2006). Freeze/thaw-induced embolism depends on nadir temperature: the heterogeneous hydration hypothesis. Plant Cell Environ. 29, 729-745. doi: 10.1111/j.1365-3040.2005.01426.x

Ball, M. C., Egerton, J. J. G., Leuning, R., Cunningham, R. B., and Dunne, P. (1997). Microclimate above grass adversely affects spring growth of seedling snow gum (Eucalyptus pauciflora). Plant Cell Environ. 20, 155-166. doi: 10.1046/j.13653040.1997.d01-61.x

Ball, M. C., Wolfe, J., Canny, M., Hofmann, M., Nicotra, A. B., and Hughes, D. (2002). Space and time dependence of temperature and freezing in evergreen leaves. Funct. Plant Biol. 29, 1259-1272. doi: 10.1071/FP02037

Bangerth, F. (2006). Flower induction in perennial fruit trees: still an enigma? Acta Hortic. 727, 177-195.

Baraer, M., Madramootoo, C. A., and Mehdi, B. B. (2010). Evaluation of winterFreeze damage risk to apple trees in global warming projections. Trans. ASABE 53, 1387-1397. doi: 10.13031/2013.34895

Barry, G., and Veldman, F. (1997). A preliminary study on the effect of girdling on fruit set and quality of Ambersweet mandarin hybrid. Citrus J. (South Africa) $7,25$.

Basler, D., and Koerner, C. (2012). Photoperiod sensitivity of bud burst in 14 temperate forest tree species. Agric. For. Meteorol. 165, 73-81. doi: 10.1016/j.agrformet.2012.06.001

Battany, M. C. (2012). Vineyard frost protection with upward-blowing wind machines. Agric. For. Meteorol. 157, 39-48. doi: 10.1016/j.agrformet.2012.01.009

Batzer, J. C., Gleason, M. L., Taylor, S. E., Koehler, K. J., and Monteiro, J. (2008). Spatial heterogeneity of leaf wetness duration in apple trees and its influence on performance of a warning system for sooty blotch and flyspeck. Plant Dis. 92, 164-170. doi: 10.1094/PDIS-92-1-0164

Bennie, J., Kubin, E., Wiltshire, A., Huntley, B., and Baxter, R. (2010). Predicting spatial and temporal patterns of bud-burst and spring frost risk in north-west Europe: the implications of local adaptation to climate. Glob. Change Biol. 16, 1503-1514. doi: 10.1111/j.1365-2486.2009.02095.x

Blennow, K. (1998). Modelling minimum air temperature in partially and clear felled forests. Agric. For. Meteorol. 91, 223-235. doi: 10.1016/S01681923(98)00069-0

Blennow, K., and Persson, P. (1998). Modelling local-scale frost variations using mobile temperature measurements with a GIS. Agric. For. Meteorol. 89, 59-71. doi: 10.1016/S0168-1923(97)00057-9

Bonhomme, M., Lacointe, A., and Rageau, R. (2013). Evidence for non-occurrence of node-to-node or stem-to-bud transfer of chilling temperature signal for dormancy release. Adv. Hortic. Sci. 27, 33-43.

Bonhomme, M., Rageau, R., Richard, J. P., Erez, A., and Gendraud, M. (1999). Influence of three contrasted climatic conditions on endodormant vegetative and floral peach buds. Analyses of their intrinsic growth capacity and their potential sink strength compared with adjacent tissues. Sci. Hortic. 80, 157-171. doi: 10.1016/S0304-4238(98)00231-3

Bory, G., Sidibe, M. D., and Clair-Maczulajtys, D. (1991). Effets du recépage sur les réserves glucidiques et lipidiques du "faux-vernis du Japon" (Ailanthus glandulosa Desf, Simarubacées). Ann. For. Sci. 48, 1-13. doi: 10.1051/forest: 19910101

Boyd, L. M., and Barnett, A. M. (2011). Manipulation of whole-vine carbon allocation using girdling, pruning, and fruit thinning affects fruit numbers and quality in kiwifruit. HortScience 46, 590-595.

Brandle, J. R., Hodges, L., and Zhou, X. H. (2004). Windbreaks in North American agricultural systems. Adv. Agrofor. 1, 65-78. doi: 10.1007/978-94-017-2424-1_5

Burke, M. J., Gusta, L. V., Quamme, H. A., Weiser, C. J., and Li, P. H. (1976). Freezing and injury in plants. Annu. Rev. Plant Physiol. Plant Mol. Biol. 27, 507-528. doi: 10.1146/annurev.pp.27.060176.002451

Canham, C. D., Kobe, R. K., Latty, E. F., and Chazdon, R. L. (1999). Interspecific and intraspecific variation in tree seedling survival: effects of allocation to roots versus carbohydrate reserves. Oecologia 121, 1-11. doi: 10.1007/s004420050900

Cannell, M. G. R., and Dewar, R. C. (eds). (1994). Carbon Allocation in Trees. A Review of Concepts for Modelling. London: Academic Press Ltd. doi: 10.1016/S0065-2504(08)60213-5
Carlson, D. W., and Groot, A. (1997). Microclimate of clear-cut, forest interior, and small openings in trembling aspen forest. Agric. For. Meteorol. 87, 313-329. doi: 10.1016/S0168-1923(95)02305-4

Carroll, A. L., and Quiring, D. T. (2003). Herbivory modifies conifer phenology: induced amelioration by a specialist folivore. Oecologia 136, 88-95. doi: 10.1007/s00442-003-1240-5

Cary, J. W. (1974). Energy-conserving system for orchard cold protection. Agric. Meteorol. 12, 339-348. doi: 10.1016/0002-1571(74)90074-0

Cellier, P. (1984). Une méthode simple de prévision des températures de l'air et de la surface du sol en conditions de gelées radiatives. Agronomie 4, 741-747. doi: 10.1051/agro:19840806

Cellier, P. (1993). An operational model for predicting minimum temperature near the soil surface under sky conditions. J. Appl. Metereol. 32, 871-883. doi: 10.1175/1520-0450(1993)032<0871:AOMFPM >2.0.CO;2

Chapin, F. S. (1991). Integrated responses of plants to stress. A centralized system of physiological responses. Bioscience 41, 29-36. doi: 10.2307/1311538

Charra-Vaskou, K., Charrier, G., Wortemann, R., Beikircher, B., Cochard, H., Améglio, T., et al. (2012). Drought and frost resistance of trees: a comparison of four species at different sites and altitudes. Ann. For. Sci. 69, 325-333. doi: 10.1007/s13595-011-0160-5

Charrier, G. (2011). Mécanismes et modélisation de l'acclimatation au gel des arbres. Application au noyer Juglans regia L. Ph.D. thèse, de l'Université Blaise Pascal, Clermont-Ferrand.

Charrier, G., and Améglio, T. (2011). The timing of leaf fall affects cold acclimation by interactions with air temperature through water and carbohydrate contents. Environ. Exp. Bot. 72, 351-357. doi: 10.1016/j.envexpbot.2010.12.019

Charrier, G., Bonhomme, M., Lacointe, A., and Améglio, T. (2011). Are budburst dates, dormancy and cold acclimation in walnut trees (Juglans regia L.) under mainly genotypic or environmental control? Int. J. Biometeorol. 55, 763-774. doi: 10.1007/s00484-011-0470-1

Charrier, G., Charra-Vaskou, K., Legros, B., Améglio, T., and Mayr, S. (2014a). Changes in ultrasound velocity and attenuation indicate freezing of xylem sap. Agric. For. Meteorol. 185, 20-25. doi: 10.1016/j.agrformet.2013.10.009

Charrier, G., Charra-Vaskou, K., Kasuga, J., Cochard, H., Mayr, S., and Améglio, T. (2014b). Freeze-thaw stress: effects of temperature on hydraulic conductivity and ultrasonic activity in ten woody angiosperms. Plant Physiol. 164, 992-998. doi: 10.1104/pp.113.228403

Charrier, G., Cochard, H., and Améglio, T. (2013a). Evaluation of the impact of frost resistances on potential altitudinal limit of trees. Tree Physiol. 33, 891-902. doi: 10.1093/treephys/tpt062

Charrier, G., Poirier, M., Bonhomme, M., Lacointe, A., and Améglio, T. (2013b). Frost acclimation in different organs of walnut trees Juglans regia L.: how to link physiology and modelling? Tree Physiol. 33, 1229-1241. doi: 10.1093/treephys/tpt090

Charrier, G., Pramsohler, M., Charra-Vaskou, K., Saudreau, M., Améglio, T., Neuner, G., et al. (2015). Ultrasonic emissions during ice nucleation and propagation in plant xylem. New Phytol. doi: 10.1111/nph.13361 [Epub ahead of print].

Chelle, M. (2005). Phylloclimate or the climate perceived by individual plant organs: what is it? How to model it? What for? New Phytol. 166, 781-790. doi: 10.1111/j.1469-8137.2005.01350.x

Chen, J. Q., Franklin, J. F., and Spies, T. A. (1993). Contrasting microclimates among clear cut, edge, and interior of old growth douglas fir forest. Agric. For. Meteorol. 63, 219-237. doi: 10.1016/0168-1923(93)90061-L

Christensen-Dalsgaard, K. K., and Tyree, M. T. (2013). Does freezing and dynamic flexing of frozen branches impact the cavitation resistance of Malus domestica and the Populus clone Walker? Oecologia 173, 665-674. doi: 10.1007/s00442013-2656-1

Christensen-Dalsgaard, K. K., and Tyree, M. T. (2014). Frost fatigue and spring recovery of xylem vessels in three diffuse-porous trees in situ. Plant Cell Environ. 37, 1074-1085. doi: 10.1111/pce.12216

Christersson, L. (1971). Frost damage resulting from ice crystal formation in seedlings of spruce and pine. Physiol. Plant. 25, 273-278. doi: 10.1111/j.13993054.1971.tb01442.x

Christersson, L. (1978). The influence of photoperiod and temperature on the development of frost hardiness in seedlings of Pinus sylvestris and Picea abies. Physiol. Plant. 44, 288-294. doi: 10.1111/j.1399-3054.1978.tb08634.x

Chuine, I., Bonhomme, M., Legave, J. M., Garcia de Cortazar-Atauri, I., Charrier, G., Lacointe, A., et al. (2014). "Can phenological models predict tree phenology 
accurately under climate change conditions?," in EGU General Assembly Conference Abstracts, Vol. 16 (Munich: European Geosciences Union), 12973.

Cinotti, B. (1991). Recherche de propriétés intrinsèques du bois pouvant expliquer la sensibilité à la gélivure de Quercus petraea (Liebl) et Q robur (L). Ann. For. Sci. 48, 453-468. doi: 10.1051/forest:19910408

Cittadini, E. D., de Ridder, N., Peri, P. L., and van Keulen, H. (2006). A method for assessing frost damage risk in sweet cherry orchards of South Patagonia. Agric. For. Meteorol. 141, 235-243. doi: 10.1016/j.agrformet.2006.10.011

Clair-Maczulatjis, D., and Bory, G. (1988). Effects of pruning treatments on the distribution of reserve carbohydrates in 2 ornemental trees (Platanus acerifolia Willd and Tilia platyphyllos Scop). Actual. Bot. 135, 41-53.

Cleavitt, N. L., Fahey, T. J., Groffman, P. M., Hardy, J. P., Henry, K. S., and Driscoll, C. T. (2008). Effects of soil freezing on fine roots in a northern hardwood forest. Can. J. For. Res. 38, 82-91. doi: 10.1139/X07-133

Coleman, W. K., Estabrooks, E. N., O'Hara, M., Embleton, J., and King, R. R. (1992). Seasonal changes in cold hardiness, sucrose and sorbitol in apple trees treated with plant growth regulators. J. Hortic. Sci. 67, 429-435.

Comerford, D. P., Schaberg, P. G., Templer, P. H., Socci, A. M., Campbell, J. L., and Wallin, K. F. (2013). Influence of experimental snow removal on root and canopy physiology of sugar maple trees in a northern hardwood forest. Oecologia 171, 261-269. doi: 10.1007/s00442-012-2393-x

Coutts, M. P., Walker, C., and Burnand, A. C. (1990). Effects of establishment method on root form of lodgepole pine and Sitka spruce and on the production of adventitious roots. Forestry 63, 143-159. doi: 10.1093/forestry/ 63.2.143

Crawford, R. M. M. (1997). Oceanicity and the ecological disadvantages of warm winters. Bot. J. Scotl. 49, 205-221. doi: 10.1080/03746609708684867

Crawford, R. M. M. (2000). Ecological hazards of oceanic environments. New Phytol. 147, 257-281. doi: 10.1046/j.1469-8137.2000.00705.x

Crawford, R. M. M., and Palin, M. A. (1981). Root respiration and temperature limits to the north south distribution of four perennial maritime species. Flora $171,338-354$.

Dai, J., Wang, H., and Ge, Q. (2013). The decreasing spring frost risks during the flowering period for woody plants in temperate area of eastern China over past 50 years. J. Geogr. Sci. 23, 641-652. doi: 10.1007/s11442-013-1034-6

Dantec, C. F., Vitasse, Y., Bonhomme, M., Louvet, J. M., Kremer, A., and Delzon, S. (2014). Chilling and heat requirements for leaf unfolding in European beech and sessile oak populations at the southern limit of their distribution range. Int. J. Biometeorol. 58, 1853-1864. doi: 10.1007/s00484-014-0787-7

Davis, S. D., Sperry, J. S., and Hacke, U. G. (1999). The relationship between xylem conduit diameter and cavitation caused by freezing. Am. J. Bot. 86, 1367-1372. doi: $10.2307 / 2656919$

Decourteix, M., Alves, G., Bonhomme, M., Peuch, M., Ben Baaziz, K., Brunel, N., et al. (2008). Sucrose (JrSUT1) and hexose (JrHT1 and JrHT2) transporters in walnut xylem parenchyma cells: their potential role in early events of growth resumption. Tree Physiol. 28, 215-224. doi: 10.1093/treephys/ 28.2.215

Decourteix, M., Alves, G., Brunel, N., Améglio, T., Guilliot, A., Lemoine, R., et al. (2006). JrSUT1, a putative xylem sucrose transporter, could mediate sucrose influx into xylem parenchyma cells and be up-regulated by freeze-thaw cycles over the autumn-winter period in walnut tree (Juglans regia L.). Plant Cell Environ. 29, 36-47. doi: 10.1111/j.1365-3040.2005.01398.x

Den, A., and Son, L. (2000). Pruning affects carbohydrate accumulation in the shoots and leaves of 'Precoce de Tyrinthe' apricot. J. Hortic. Sci. Biotechnol. 75, 539-541.

Demirtas, N. M., Bolat, I., Ercisli, S., Ikinci, A., Olmez, H., Sahin, M., et al. (2010). The effects of different pruning treatments on seasonal variation of carbohydrates in 'Hacihaliloglu' apricot cultivar. Not. Bot. Horti Agrobot. Cluj Napoca 38, 223-227.

Derby, R. W., and Gates, D. M. (1966). The temperature of tree trunks-calculated and observed. Am. J. Bot. 53, 580-587. doi: 10.2307/2440008

Dereuddre, J., and Gazeau, C. (1992). "Les végétaux et les très basses températures," in Les végétaux et le froid, ed. D. Côme (Paris: Hermann), 107-175.

Dowgert, M. F., and Steponkus, P. L. (1984). Behavior of the plasma-membrane of isolated protoplasts during a freeze-thaw cycle. Plant Physiol. 75, 1139-1151. doi: 10.1104/pp.75.4.1139

Eccel, E., Rea, R., Caffarra, A., and Crisci, A. (2009). Risk of spring frost to apple production under future climate scenarios: the role of phenological acclimation. Int. J. Biometeorol. 53, 273-286. doi: 10.1007/s00484-009-0213-8
Elle, D., and Sauter, J. J. (2000). Seasonal changes of activity of a starch granule bound endoamylase and of a starch phosphorylase in poplar wood (Populus $\times$ canadensis Moench 'Robusta') and their possible regulation by temperature and phytohormones. J. Plant Physiol. 156, 731-740. doi: 10.1016/S01761617(00)80239-4

Ensminger, I., Busch, F., and Huner, N. P. A. (2006). Photostasis and cold acclimation: sensing low temperature through photosynthesis. Physiol. Plant. 126, 28-44. doi: 10.1111/j.1399-3054.2006.00627.x

Epron, D., Bahn, M., Derrien, D., Lattanzi, F. A., Pumpanen, J., Gessler, A., et al. (2012). Pulse-labelling trees to study carbon allocation dynamics: a review of methods, current knowledge and future prospects. Tree Physiol. 32, 776-798. doi: 10.1093/treephys/tps057

Ewers, F. W., Améglio, T., Cochard, H., Beaujard, F., Martignac, M., Vandame, M., et al. (2001). Seasonal variation in xylem pressure of walnut trees: root and stem pressures. Tree Physiol. 21, 1123-1132. doi: 10.1093/treephys/21.15.1123

Fady, B., Ducci, F., Aleta, N., Becquey, J., Vazquez, R. D., Lopez, F. F., et al. (2003). Walnut demonstrates strong genetic variability for adaptive and wood quality traits in a network of juvenile field tests across Europe. New For. 25, 211-225. doi: 10.1023/A:1022939609548

Field, C. B., Barros, V. R., Dokken, D. J., Mach, K. J., Mastranda, M. D., Bilir, T. E., et al. (2014). IPCC 2014: Climate Change 2014: Impacts, Adaptation, and Vulnerability. Part A: Global and Sectoral Aspects. Contribution of Working Group II to the Fifth Assessment Report of the Intergovernmental Panel on Climate Change. Cambridge: Cambridge University Press.

Fitter, A. H., Graves, J. D., Self, G. K., Brown, T. K., Bogie, D. S., and Taylor, K. (1998). Root production, turnover and respiration under two grassland types along an altitudinal gradient: influence of temperature and solar radiation. Oecologia 114, 20-30. doi: 10.1007/s004420050415

Fitter, A. H., Self, G. K., Brown, T. K., Bogie, D. S., Graves, J. D., Benham, D., et al. (1999). Root production and turnover in an upland grassland subjected to artificial soil warming respond to radiation flux and nutrients, not temperature. Oecologia 120, 575-581. doi: 10.1007/s004420050892

Fornari, B., Malvolti, M. E., Taurchini, D., Fineschi, S., Beritognolo, I., Maccaglia, E., et al. (2001). Isozyme and organellar DNA analysis of genetic diversity in natural/naturalised European and Asiatic walnut (Juglans regia L.) populations. Acta Hortic. 544, 167-178.

Forrester, D. I. (2013). Growth responses to thinning, pruning and fertiliser application in Eucalyptus plantations: a review of their production ecology and interactions. For. Ecol. Mange. 310, 336-347. doi: 10.1016/j.foreco.2013. 08.047

Forrester, D. I., Collopy, J. J., Beadle, C. L., and Baker, T. G. (2013). Effect of thinning, pruning and nitrogen fertiliser application on light interception and light-use efficiency in a young Eucalyptus nitens plantation. For. Ecol. Mange. 288, 21-30. doi: 10.1016/j.foreco.2011.11.024

Franklin, O., Johansson, J., Dewar, R. C., Dieckmann, U., McMurtrie, R. E., Brännström, Å., et al. (2012). Modeling carbon allocation in trees: a search for principles. Tree Physiol. 32, 648-666. doi: 10.1093/treephys/tpr138

Francesconi, A. H. D., Lakso, A. N., Nyrop, J. P., Barnard, J., and Denning, S. S. (1996). Carbon balance as a physiological basis for the interactions of European red mite and crop load on 'Starkrimson Delicious' apple trees. J. Am. Soc. Hortic. Sci. 121, 959-966.

Friedland, A. J., Boyce, R. L., Vostral, C. B., and Herrick, G. T. (2003). Winter and early spring microclimate within a mid-elevation conifer forest canopy. Agric. For. Meteorol. 115, 195-200. doi: 10.1016/S0168-1923(02)00200-9

Friend, A. P., Trought, M. C. T., Stushnoff, C., and Wells, G. H. (2011). Effect of delaying budburst on shoot development and yield of Vitis vinifera L. Chardonnay 'Mendoza' after a spring freeze event. Aust. J. Grape Wine Res. 17, 378-382. doi: 10.1111/j.1755-0238.2011.00162.x

Fuchigami, L. H., Weiser, C. J., Kobayashi, K., Timmis, R., and Gusta, L. V. (1982). "A degree growth stage (degree GS) model and cold acclimation in temperate woody plants," in Plant Cold Hardiness and Freezing Stress. Mechanisms and Crop Implications, Vol. 2, ed. P. H. Li (New York, NY: Academic Press), 93-116.

Fumey, D., Lauri, P. E., Guedon, Y., Godin, C., and Costes, E. (2011). How young trees cope with removal of whole or parts of shoots: an analysis of local and distant responses to pruning in 1-year-old apple (Malus $\times$ domestica; Rosaceae) trees. Am. J. Bot. 98, 1737-1751. doi: 10.3732/ajb.1000231

Galvez, D. A., Landhaeusser, S. M., and Tyree, M. T. (2013). Low root reserve accumulation during drought may lead to winter mortality in poplar seedlings. New Phytol. 198, 139-148. doi: 10.1111/nph.12129 
Gansert, D. (2004). Treelines of the Japanese Alps-altitudinal distribution and species composition under contrasting winter climates. Flora 199, 143-156. doi: 10.1078/0367-2530-00143

Genard, M., Dauzat, J., Franck, N., Lescourret, F., Moitrier, N., Vaast, P., et al. (2008). Carbon allocation in fruit trees: from theory to modelling. Trees 22, 269-282. doi: 10.1007/s00468-007-0176-5

Gloser, V., Zwieniecki, M. A., Orians, C. M., and Holbrook, N. M. (2007). Dynamic changes in root hydraulic properties in response to nitrate availability. J. Exp. Bot. 58, 2409-2415. doi: 10.1093/jxb/erm118

Gordon, D., and Dejong, T. M. (2007). Current-year and subsequent-year effects of crop-load manipulation and epicormic-shoot removal on distribution of long, short and epicormic shoot growth in Prunus persica. Ann. Bot. 99, 323-332. doi: $10.1093 / \mathrm{aob} / \mathrm{mcl} 262$

Goren, R., Huberman, M., and Goldschmidt, E. E. (2004). "Girdling: physiological and horticultural aspects," Vol. 30, Horticultural reviews, ed. J. Janick (Wiley \& Sons), 1-36.

Gorsuch, D. M., and Oberhauer, S. F. (2002). Effects of mid-season frost and elevated growing season temperature on stomatal conductance and specific xylem conductivity of the arctic shrub, Salix pulchra. Tree Physiol. 22, 1027-1034. doi: $10.1093 /$ treephys/22.14.1027

Grant, R. H. (1984). The mutual interference of spruce canopy structural elements. Agric. For. Meteorol. 32, 145-156. doi: 10.1016/0168-1923(84)90084-4

Greer, D. H., and Warrington, I. J. (1982). Effect of photoperiod, night temperature, and frost incidence on development of frost hardiness in Pinus radiata. Aust. J. Plant Physiol. 9, 333-342. doi: 10.1071/PP9820333

Grime, J. P. (1977). Evidence for the existence of three primaries strategies in plants and its relevance to ecological and evolutionary theory. Am. Nat. 111, 1169-1194. doi: 10.1086/283244

Gu, L., Hanson, P. J., Mac Post, W., Kaiser, D. P., Yang, B., Nemani, R., et al. (2008). The 2007 eastern US spring freezes: increased cold damage in a warming world? Bioscience 58, 253-262. doi: 10.1641/B580311

Gusta, L. V., Tyler, N. J., and Chen, T. H. H. (1983). Deep undercooling in woody taxa growing north of the $-40^{\circ} \mathrm{C}$ isotherm. Plant Physiol. 72, 122-128. doi: 10.1104/pp.72.1.122

Gusta, L. V., Wisniewski, M., Nesbitt, N. T., and Gusta, M. L. (2004). The effect of water, sugars, and proteins on the pattern of ice nucleation and propagation in acclimated and non acclimated canola leaves. Plant Physiol. 135, 1642-1653. doi: 10.1104/pp.103.028308

Hacke, U. G., and Sperry, J. S. (2001). Functional and ecological xylem anatomy. Perspect. Plant Ecol. Evol. Syst. 4, 97-115. doi: 10.1078/1433-8319-00017

Hacker, J., Ladinig, U., Wagner, J., and Neuner, G. (2011). Inflorescences of alpine cushion plants freeze autonomously and may survive subzero temperatures by supercooling. Plant Sci. 180, 149-156. doi: 10.1016/j.plantsci.2010.07.013

Haddad, Y., Clair-Maczulatjis, D., and Bory, G. (1992). Effects of curtain-like pruning on distribution and seasonal patterns of carbohydrate reserves in plane (Platanus acerifolia Wild) trees. Tree Physiol. 15, 135-140. doi: 10.1093/treephys/15.2.135

Hallé, F., Oldeman, R. A. A., and Tomlinson, P. B. (1978). Tropical Trees and Forests. An Architectural Analysis. Heidelberg: Springer Verlag. doi: 10.1007/978-3-64281190-6

Hamer, P. J. C. (1985). The heat balance of apple buds and blossoms.1. Heat transfer in the outdoor environment. Agric. For. Meteorol. 35, 339-352. doi: 10.1016/0168-1923(85)90094-2

Hanninen, H. (1991). Does climatic warming increase the risk of frost damage in northern trees? Plant Cell Environ. 14, 449-454. doi: 10.1111/j.13653040.1991.tb01514.x

Hänninen, H., and Kramer, K. (2007). A Framework for modelling the annual cycle of trees in boreal and temperate regions. Silva Fennica 41, 167-205. doi: $10.14214 /$ sf.313

Haouari, A., Van Labeke, M. C., Steppe, K., Ben Mariem, F., Braham, M., and Chaieb, M. (2013). Fruit thinning affects photosynthetic activity, carbohydrate levels, and shoot and fruit development of olive trees grown under semiarid conditions. Funct. Plant Biol. 40, 1179-1186. doi: 10.1071/FP13094

Hoch, G., and Koerner, C. (2009). Growth and carbon relations of tree line forming conifers at constant vs. variable low temperatures. J. Ecol. 97, 57-66. doi: 10.1111/j.1365-2745.2008.01447.x

Hoch, G., and Koerner, C. (2012). Global patterns of mobile carbon stores in trees at the high-elevation tree line. Glob. Ecol. Biogeogr. 21, 861-871. doi: $10.1111 /$ j.1466-8238.2011.00731.x
Inouye, D. (2008). Effects of climate change on phenology, frost damage, and floral abundance of montane wildflowers. Ecology 89, 353-362. doi: 10.1890/06-2128.1

Ishida, S. (1963). On the development of frost cracks on Todomatsu trunks, Abies sachalinensis especially in relation to their wetwood. Res. Bull. Col. Exp. For. Hokkaido University 22, 273-373.

Itier, B., Flura, D., Brun, O., Luisetti, J., Gaignard, J. L., Choisy, C., et al. (1991). An analysis of sensitivity to spring frost in vine buds. Agronomie 11, 169-174. doi: 10.1051/agro:19910303

Itier, B., Flura, D., Brun, O., Luisetti, J., Gaignard, J. L., Choisy, C., et al. (1993). Etude experimentale de la gelivite des bourgeons de vigne in situ. Agronomie 11, 169-174.

Ito, A., Sugiura, T., Sakamoto, D., and Moriguchi, T. (2013). Effects of dormancy progression and low-temperature response on changes in the sorbitol concentration in xylem sap of Japanese pear during winter season. Tree Physiol. 33, 398-408. doi: 10.1093/treephys/tpt021

Jones, K. S., McKersie, B. D., and Paroschy, J. (2000). Prevention of ice propagation by permeability barriers in bud axes of Vitis vinifera. Can. J. Bot. 78, 3-9. doi: 10.1139/cjb-78-1-3

Jordan, D. N., and Smith, W. K. (1994). Energy balance analysis of nighttime leaf temperatures and frost formation in a sub alpine environment. Agric. For. Meteorol. 71, 359-372. doi: 10.1016/0168-1923(94)90020-5

Kaku, S., and Iwaya, M. (1979). Deep supercooling in xylems and ecological distribution in the genera Ilex, Viburnum and Quercus in Japan. Oikos 33, 402-411. doi: $10.2307 / 3544328$

Kalberer, S. R., Wisniewski, M., and Arora, R. (2006). Deacclimation and reacclimation of cold-hardy plants: current understanding and emerging concepts. Plant Sci. 171, 3-16. doi: 10.1016/j.plantsci.2006.02.013

Kalcsits, L. A., Silim, S., and Tanino, K. (2009). Warm temperature accelerates short photoperiod-induced growth cessation and dormancy induction in hybrid poplar (Populus $\times$ spp.). Trees 23, 971-979. doi: 10.1007/s00468-009-0339-7

Kasuga, J., Charrier, G., Uemura, M., and Améglio, T. (2015). Characteristics of ultrasonic acoustic emissions from walnut twigs during freeze-thaw-induced embolism formation. J. Exp. Bot. 66, 1965-1975. doi: 10.1093/jxb/eru543

Kawamura, K. (2010). A conceptual Framework for the study of modular responses to local environmental heterogeneity within the plant crown and a review of related concepts. Ecol. Res. 25, 733-744. doi: 10.1007/s11284-009-0688-0

Khanizadeh, S., Buszard, D., and Zarkadas, C. G. (1992). Effect of crop load on hardiness, protein and amino acids content of apple flower buds at the wintering stage and the beginning of the growth. J Plant Nutr. 15, 2441-2455. doi: $10.1080 / 01904169209364486$

Koerner, C. (1998). A re-assessment of high elevation treeline positions and their explanation. Oecologia 115, 445-459. doi: 10.1007/s004420050540

Kollas, C., Koerner, C., and Randin, C. F. (2014). Spring frost and growing season length co-control the cold range limits of broad-leaved trees. J. Biogeogr. 41, 773-783. doi: 10.1111/jbi.12238

Kreyling, J., Buhk, C., Backhaus, S., Hallinger, M., Huber, G., Huber, L., et al. (2014). Local adaptations to frost in marginal and central populations of the dominant forest tree Fagus sylvatica L. as affected by temperature and extreme drought in common garden experiments. Ecol. Evol. 4, 594-605. doi: 10.1002/ece3.971

Kreyling, J., Wiesenberg, G. L. B., Thiel, D., Wohlfart, C., Huber, G., Walter, J., et al. (2012). Cold hardiness of Pinus nigra Arnold as influenced by geographic origin, warming, and extreme summer drought. Environ. Exp. Bot. 78, 99-108. doi: 10.1016/j.envexpbot.2011.12.026

Krezdorn, A. H. (1960). The influence of girdling on the fruiting of 'Orlando' tangelos and navel oranges. Proc. Florida State Hortic. Soc. 73, 49-52.

Kuhrt, U., Samietz, J., and Dorn, S. (2006). Effect of plant architecture and hail nets on temperature of codling moth habitats in apple orchards. Entomol. Exp. Appl. 118, 245-259. doi: 10.1111/j.1570-7458.2006.00385.x

Kuprian, E., Briceño, V. F., Wagner, J., and Neuner, G. (2014). Ice barriers promote supercooling and prevent frost injury in reproductive buds, flowers and fruits of alpine dwarf shrubs throughout the summer. Environ. Exp. Bot. 106, 4-12. doi: 10.1016/j.envexpbot.2014.01.011

Lacointe, A. (2000). Carbon allocation among tree organs: a review of basic processes and representation in functional-structural tree models. Ann. For. Sci. 57, 521-533. doi: 10.1051/forest:2000139

Ladinig, U., Hacker, J., Neuner, G., and Wagner, J. (2013). How endangered is sexual reproduction of high-mountain plants by summer frosts? Frost resistance, frequency of frost events and risk assessment. Oecologia 171, 743-760. doi: $10.1007 / \mathrm{s} 00442-012-2581-8$ 
Lakatos, L., Dussi, M. C., Gonda, I., Soltesz, M., Nyeki, J., Szabo, Z., et al. (2011). Microclimate modification in pear plantation by using cooling irrigation. Acta Hortic. 909, 631-638.

Lamhamedi, M. S., and Bernier, P. Y. (1994). Ecophysiology and field performance of black spruce (Picea mariana): a review. Ann. For. Sci. 51, 529-551. doi: 10.1051/forest:19940601

Landsberg, J. J., Beadle, C. L., Biscoe, P. V., Butler, D. R., Davidson, B., Incoll, L. D., et al. (1975). Diurnal energy, water and $\mathrm{CO}_{2}$ exchanges in an apple (Malus pumila) orchard. J. Appl. Ecol. 12, 659-684. doi: 10.2307/2402181

Landsberg, J. J., and Thom, A. S. (1971). Aerodynamic properties of a plant of complex structure. Q. J. R. Meteorol. Soc. 97, 565-570. doi: 10.1002/qj.49709741418

Lang, G. A., Early, J. D., Martin, G. C., and Darnell, R. L. (1987). Endo-, paraand ecodormancy: physiological terminology and classification for dormancy research. HortScience 22, 371-377.

Larcher, W. (1985). "Kälte und frost," in Handbuch der Pflanzenökologie, ed. P. Sorauer (Berlin: Parey), 107-326.

Larcher, W. (2005). Climatic constraints drive the evolution of low temperature resistance in woody plants. J. Agric. Meteorol. 61, 189-202. doi: 10.2480/agrmet.61.189

Larcher, W., and Mair, B. (1968). Das kälteresistenzverhalten von Quercus pubescens, Ostrya carpinifolia und Fraxinus ornus auf drei thermisch unterschiedlichen standorten. Oecol. Plant. 3, 255-270.

Larcher, W., Kainmueller, C., and Wagner, J. (2010). Survival types of high mountain plants under extreme temperatures. Flora 205, 3-18. doi: 10.1016/j.flora.2008.12.005

Lardon, A., and Triboi-Blondel, A. M. (1994). Freezing injury to ovules, pollen and seeds in winter rape. J. Exp. Bot. 45, 1177-1181. doi: 10.1093/jxb/45.8.1177

Laube, J., Sparks, T. H., Estrella, N., Hofler, J., Ankerst, D. P., and Menzel, A. (2014). Chilling outweighs photoperiod in preventing precocious spring development. Glob. Change Biol. 20, 170-182. doi: 10.1111/gcb. 12360

Le Roux, X., Lacointe, A., Escobar-Gutierrez, A., and Le Dizes, S. (2001). Carbonbased models of individual tree growth: a critical appraisal. Ann. For. Sci. 58, 469-506. doi: 10.1051/forest:2001140

Lee, S. H., Chung, G. C., Jang, J. Y., Ahn, S. J., and Zwiazek, J. J. (2012). Overexpression of PIP2;5 aquaporin alleviates effects of low root temperature on cell hydraulic conductivity and growth in Arabidopsis. Plant Physiol. 159, 479-488. doi: $10.1104 /$ pp.112.194506

Leinonen, I. (1996). A Simulation Model for the annual frost hardiness and freezing damage of Scots pine. Ann. Bot. 78, 687-693. doi: 10.1006/anbo.1996.0178

Lemoine, D., Granier, A., and Cochard, H. (1999). Mechanism of freeze-induced embolism in Fagus sylvatica L. Trees 13, 206-210. doi: 10.1007/PL00009751

Lenz, A., Hoch, G., Vitasse, Y., and Koerner, C. (2013). European deciduous trees exhibit similar safety margins against damage by spring freeze events along elevational gradients. New Phytol. 200, 1166-1175. doi: 10.1111/nph.12452

Leuning, R. (1988). Leaf temperature during radiation frost. 2. A steady state theory. Agric. For. Meteorol. 42, 135-155. doi: 10.1016/0168-1923(88)90073-1

Leuning, R., and Cremer, K. W. (1988). Leaf temperature during radiation frost. 1. Observations. Agric. For. Meteorol. 42, 121-133. doi: 10.1016/01681923(88)90072-X

Levitt, J. (1980). "Responses of plants to environmental stresses: chilling, freezing, and high temperature stress," in Physiological Ecology: A Series of Monographs, Texts and Treatises, 2n Edn, Vol. 1, ed. Kozlowsky (New York, NY: Academic Press), 23-64.

Li, P. H., and Weiser, C. J. (1971). Increasing cold resistance of stem sections of Cornus stolonifera by artificial dehydration: a preliminary report. Cryobiology 8 , 108-111. doi: 10.1016/0011-2240(71)90111-8

Lieffers, V. J., and Rothwell, R. L. (1986). Effects of depth of water table and substrate temperature on root and top growth of Picea mariana and Larix lancina seedlings. Can. J. For. Res. 16, 1201-1206. doi: 10.1139/x86-214

Lim, C. C., Krebs, S. L., and Arora, R. (2014). Cold hardiness increases with age in juvenile Rhododendron populations. Front. Plant Sci. 5:542. doi: 10.3389/fpls.2014.00542

Linares, J. C., Covelo, F., Carreira, J. A., and Merino, J. A. (2012). Phenological and water-use patterns underlying maximum growing season length at the highest elevations: implications under climate change. Tree Physiol. 32, 161-170. doi: 10.1093/treephys/tps003

Lindkvist, L., Gustavsson, T., and Bogren, J. (2000). A frost assessment method for mountainous areas. Agric. For. Meteorol. 102, 51-67. doi: 10.1016/S01681923(99)00087-8
Linkosalo, T., Carter, T. R., Hakkinen, R., and Hari, P. (2000). Predicting spring phenology and frost damage risk of Betula spp. under climatic warming: a comparison of two models. Tree Physiol. 20, 1175-1182. doi: 10.1093/treephys/20.17.1175

Linkosalo, T., Hakkinen, R., and Hanninen, H. (2006). Models of the spring phenology of boreal and temperate trees: is there something missing? Tree Physiol. 26, 1165-1172. doi: 10.1093/treephys/26.9.1165

Lopez, G., Girona, J., and Marsal, J. (2007). Response of winter root starch concentration to severe water stress and fruit load and its subsequent effects on early peach fruit development. Tree Physiol. 27, 1619-1626. doi: 10.1093/treephys/27.11.1619

Lyons, J. M., and Raison, J. K. (1970). Oxidative activity of mitochondria isolated from plant tissues sensitive and resistant to chilling injury. Plant Physiol. 45, 386-389. doi: 10.1104/pp.45.4.386

Mai, J., Herbette, S., Vandame, M., Kositsup, B., Kasemsap, P., Cavaloc, E., et al. (2009). Effect of chilling on photosynthesis and antioxidant enzymes in Hevea brasiliensis Muell. Arg. Trees 23, 863-874. doi: 10.1007/s00468-0090328-x

Man, R., Colombo, S., Kayahara, G. J., Duckett, S., Velasquez, R., and Dang, Q. L. (2013). A case of extensive conifer needle browning in northwestern Ontario in 2012: winter drying or freezing damage? For. Chron. 89, 675-680. doi: $10.5558 / \mathrm{tfc} 2013-120$

Manchester, S. R. (1989). Early history of the Juglandaceae. Plant Syst. Evol. 162, 231-250. doi: 10.1007/BF00936919

Manoury-Danger, F., Fresneau, C., Eglin, T., Berveiller, D., Francois, C., LelargeTrouverie, C., et al. (2010). Impact of carbohydrate supply on stem growth, wood and respired $\mathrm{CO}_{2} \delta^{13} \mathrm{C}$ : assessment by experimental girdling. Tree Physiol. 30, 818-830. doi: 10.1093/treephys/tpq039

Marafon, A. C., Citadin, I., do Amarante, L., Herter, F. G., and Hawerroth, F. J. (2011). Chilling privation during dormancy period and carbohydrate mobilization in Japanese pear trees. Sci. Agric. 68, 462-468. doi: 10.1590/S010390162011000400011

Mataa, M., Tominaga, S., and Kozaki, I. (1998). The effect of time of girdling on carbohydrate contents and fruiting in Ponkan mandarin (Citrus reticulata Blanco). Sci. Hortic. 73, 203-211. doi: 10.1016/S0304-4238(98)00086-7

Mayr, S., and Charra-Vaskou, K. (2007). Winter at the alpine timberline causes complex within-tree patterns of water potential and embolism in Picea abies. Physiol. Plant. 131, 131-139. doi: 10.1111/j.1399-3054.2007.00942.x

Mayr, S., Cochard, H., Améglio, T., and Kikuta, S. B. (2007). Embolism formation during freezing in the wood of Picea abies. Plant Physiol. 143, 60-67. doi: 10.1104/pp.106.085704

Mayr, S., Gruber, A., and Bauer, H. (2003). Repeated freeze-thaw cycles induce embolism in drought stressed conifers (Norway spruce, stone pine). Planta 217 436-441. doi: 10.1007/s00425-003-0997-4

Mayr, S., Schmid, P., Laur, J., Rosner, S., Charra-Vaskou, K., Damon, B., et al. (2014). Uptake of water via branches helps timberline conifers refill embolized xylem in late winter. Plant Physiol. 164, 1731-1740. doi: 10.1104/pp.114. 236646

Mayr, S., and Sperry, J. S. (2010). Freeze-thaw-induced embolism in Pinus contorta: centrifuge experiments validate the 'thaw-expansion hypothesis' but conflict with ultrasonic emission data. New Phytol. 185, 1016-1024. doi: 10.1111/j.14698137.2009.03133.x

Mayr, S., Wieser, G., and Bauer, H. (2006). Xylem temperatures during winter in conifers at the alpine timberline. Agric. For. Meteorol. 137, 81-88. doi: 10.1016/j.agrformet.2006.02.013

Mayr, S., Wolfschwenger, M., and Bauer, H. (2002). Winter-drought induced embolism in Norway spruce (Picea abies) at the Alpine timberline. Physiol. Plant. 115, 74-80. doi: 10.1034/j.1399-3054.2002.1150108.x

McAneney, K. J., Salinger, M. J., Porteous, A. S., and Barber, R. F. (1990). Modification of an orchard climate with increasing shelter belt height. Agric. For. Meteorol. 49, 177-189. doi: 10.1016/0168-1923(90)90031-Z

McQueen, J. C., Silvester, W. B., Green, T. G. A., and Minchin, P. E. H. (2004) "Carbohydrate allocation in apple stems can be altered by fruit load," in Key Processes in the Growth and Cropping of Deciduous Fruit and Nut Trees. International Society Horticultural Science, ed. A. D. Webster (Leuven: Acta Horticulturae 636), 267-273.

Medeiros, J. S., and Pockman, W. T. (2010). Carbon gain and hydraulic limits on water use differ between size classes of Larrea tridentata. J. Arid Environ. 74, 1121-1129. doi: 10.1016/j.jaridenv.2010.05.008 
Michaletz, S. T., and Johnson, E. A. (2006). Foliage influences forced convection heat transfer in conifer branches and buds. New Phytol. 170, 87-98. doi: 10.1111/j.1469-8137.2006.01661.x

Minchin, P. E. H., and Lacointe, A. (2005). New understanding on phloem physiology and possible consequences for modelling long-distance carbon transport. New Phytol. 166, 771-779. doi: 10.1111/j.1469-8137.2005.01323.x

Mirás-Avalos, J. M., Alcobendas, R., Alarcón, J. J., Pedrero, F., Valsesia, P., Lescourret, F., et al. (2013). Combined effects of water stress and fruit thinning on fruit and vegetative growth of a very early-maturing peach cultivar: assessment by means of a fruit tree model, QualiTree. Irrigat. Sci. 31, 1039-1051. doi: 10.1007/s00271-012-0385-6

Mitchell, P. J., O'Grady, A. P., Tissue, D. T., Worledge, D., and Pinkard, E. A. (2014). Co-ordination of growth, gas exchange and hydraulics define the carbon safety margin in tree species with contrasting drought strategies. Tree Physiol. 34, 443-458. doi: 10.1093/treephys/tpu014

Monteith, J. L. (1972). Solar radiation and productivity in tropical ecosystems. J. Appl. Ecol. 9, 747-766. doi: 10.2307/2401901

Monteith, J. L., and Unsworth, M. H. (eds). (1990). Principles of Environmental Physics. London: Edward Arnold.

Moran, R. E., Sun, Y., Geng, F., and Zhang, D. (2011). Cold temperature tolerance of trunk and root tissues in one- or two-year-old apple rootstocks. Hortic. Sci. 46, 1460-1464.

Morin, X., Améglio, T., Ahas, R., Kurz-Besson, C., Lanta, V., Lebourgeois, F., et al. (2007). Variation in cold hardiness and carbohydrate concentration from dormancy induction to bud burst among provenances of three European oak species. Tree Physiol. 27, 817-825. doi: 10.1093/treephys/27.6.817

Muldrew, K., Acker, J. P., Elliott, J. A. W., and McGann, L. E. (2004). “The Water to Ice transition: implications for living cells," in Life in the Frozen State, eds B. J. Fuller, N. Lane, and E. E. Benson (Boca Raton, FL: CRC Press), 67-107. doi: 10.1201/9780203647073.ch2

Murray, M. B., Cannell, M. G. R., and Smith, R. I. (1989). Date of budburst of fifteen species in Britain following climate warming. J. Appl. Ecol. 26, 693-700. doi: $10.2307 / 2404093$

Neuner, G., Erler, A., Ladinig, U., Hacker, J., and Wagner, J. (2013). Frost resistance of reproductive tissues during various stages of development in high mountain plants. Physiol. Plant. 147, 88-100. doi: 10.1111/j.1399-3054.2012.01616.x

Nicoll, B. C., and Coutts, M. P. (1998). Timing of root dormancy and tolerance to root waterlogging in clonal Sitka spruce. Trees 12, 241-245. doi: $10.1007 / \mathrm{s} 004680050147$

Niinemets, U. (2010). Responses of forest trees to single and multiple environmental stresses from seedlings to mature plants. Past stress history, stress interactions, tolerance and acclimation. For. Ecol. Manage. 260, 1623-1639. doi: 10.1016/j.foreco.2010.07.054

Nikula, S., Manninen, S., and Pulkkinen, P. (2011). Growth and frost hardening of European aspen and backcross hybrid aspen as influenced by water and nitrogen. Ann. For. Sci. 68, 737-745. doi: 10.1007/s13595-011-0090-2

Nobel, P. S. (1974). "Introduction to biophysical plant physiology," in A Series of Books in Biology, (San Francisco, CA: Freeman and Company), 488.

Nobel, P. S. (1980). Morphology, nurse plants, and minimum apical temperatures for young Carnegiea gigantea. Bot. Gaz. 141, 188-191. doi: 10.1086/337142

Ögren, E. (2000). Maintenance respiration correlates with sugar but not nitrogen contration in dormant plants. Physiol. Plant. 108, 295-299. doi: 10.1034/j.13993054.2000.108003295.x

Pagter, M., and Williams, M. (2011). Frost dehardening and rehardening of Hydrangea macrophylla stems and buds. HortScience 46, 1121-1126.

Pagter, M., Hausman, J. F., and Arora, R. (2011). Deacclimation kinetics and carbohydrate changes in stem tissues of Hydrangea in response to an experimental warm spell. Plant Sci. 180, 140-148. doi: 10.1016/j.plantsci.2010. 07.009

Palonen, P., and Buszard, D. (1997). Current state of cold hardiness research on fruit crops. Can. J. Plant Sci. 77, 399-420. doi: 10.4141/P96-013

Palonen, P., and Linden, L. (1999). Dormancy, cold hardiness, dehardening, and rehardening in selected red raspberry cultivars. J. Am. Soc. Hortic. Sci. 124, 341-346.

Pearce, R. S. (2001). Plant freezing and damage. Ann. Bot. 87, 417-424. doi: 10.1006/anbo.2000.1352

Peng, Y., Arora, R., Li, G., Wang, X., and Fessehaie, A. (2008a). Rhododendron catawbiense plasma membrane intrinsic proteins are aquaporins, and their overexpression compromises constitutive freezing tolerance and cold acclimation ability of transgenic Arabidopsis plants. Plant Cell Environ. 31, 1275-1289. doi: 10.1111/j.1365-3040.2008.01840.x

Peng, Y., Reyes, J. L., Wei, H., Yang, Y., Karlson, D., Covarrubias, A. A., et al. (2008b). RcDhn5, a cold acclimation-responsive dehydrin from Rhododendron catawbiense rescues enzyme activity from dehydration effects in vitro and enhances freezing tolerance in RcDhn5-overexpressing Arabidopsis plants. Physiol. Plant. 134, 583-597. doi: 10.1111/j.1399-3054.2008.01164.x

Phillips, J. R., Sastry, S. K., and Morrow, C. T. (1983). Prediction of sprinkler offtimes during frost protection of apple buds-a heat transfer model. Trans. ASAE 26, 1430-1434. doi: 10.13031/2013.34145

Pittermann, J., and Sperry, J. (2003). Tracheid diameter is the key trait determining the extent of freezing induced embolism in conifers. Tree Physiol. 23, 907-914. doi: 10.1093/treephys/23.13.907

Poirier, M., Lacointe, A., and Améglio, T. (2010). A semi-physiological model of cold hardening and dehardening in walnut stem. Tree Physiol. 30, 1555-1569. doi: 10.1093/treephys/tpq087

Potter, B. E., and Andresen, J. A. (2002). A finite-difference model of temperatures and heat flow within a tree stem. Can. J. For. Res. 32, 548-555. doi: 10.1139/x01226

Poyatos, R., Aguade, D., Galiano, L., Mencuccini, M., and Martinez-Vilalta, J. (2013). Drought-induced defoliation and long periods of near-zero gas exchange play a key role in accentuating metabolic decline of Scots pine. New Phytol. 200, 388-401. doi: 10.1111/nph.12278

Pramsohler, M., Hacker, J., and Neuner, G. (2012). Freezing pattern and frost killing temperature of apple (Malus domestica) wood under controlled conditions and in nature. Tree Physiol. 32, 819-828. doi: 10.1093/treephys/tps046

Pramsohler, M., and Neuner, G. (2013). Dehydration and osmotic adjustment in apple stem tissue during winter as it relates to the frost resistance of buds. Tree Physiol. 33, 807-816. doi: 10.1093/treephys/tpt057

Pretorius, J. J. B., Wand, S. J. E., and Theron, K. I. (2004). Fruit and shoot growth following combined girdling and thinning of 'Royal Gala' apple trees. Acta Hortic. 636, 401-407.

Raunkiaer, C. (1934). The Life Forms of Plants and Statistical Plant Geography. Oxford: Claredon Press.

Read, D. J. (1967). Dieback disease of pines with special reference to Corsican pine Pinus nigra var. calabrica Schn. 2. Relation between frost resistance microclimate and disease. Forestry 40, 83-97. doi: 10.1093/forestry/40.1.84

Regier, N., Streb, S., Zeeman, S. C., and Frey, B. (2010). Seasonal changes in starch and sugar content of poplar (Populus deltoides $\times$ nigra cv. Dorskamp) and the impact of stem girdling on carbohydrate allocation to roots. Tree Physiol. 30, 979-987. doi: 10.1093/treephys/tpq047

Ribeiro, A. C., de Melo-Abreau, J. P., and Snyder, R. (2006). Apple orchard frost protection with wind machine operation. Agric. For. Meteorol. 141, 71-81. doi: 10.1016/j.agrformet.2006.08.019

Richard, B., Bussière, F., Langrume, C., Rouault, F., Jumel, S., Faivre, R., et al. (2013). Effect of pea canopy architecture on microclimate and consequences on ascochyta blight infection under field conditions. Eur. J. Plant Pathol. 135 509-524. doi: 10.1007/s10658-012-0132-0

Rigby, J. R., and Porporato, A. (2008). Spring frost risk in a changing climate. Geophys. Res. Lett. 35, L12703. doi: 10.1029/2008GL033955

Rochette, P., Belanger, G., Castonguay, Y., Bootsma, A., and Mongrain, D. (2004). Climate change and winter damage to fruit trees in eastern Canada. Can. J. Plant Sci. 84, 1113-1125. doi: 10.4141/P03-177

Rodrigo, J. (2000). Spring frosts in deciduous fruit trees-morphological damage and flower hardiness. Sci. Hortic. 85, 155-173. doi: 10.1016/S03044238(99)00150-8

Rosas, T., Galiano, L., Ogaya, R., Penuelas, J., and Martinez-Vilalta, J. (2013). Dynamics of non-structural carbohydrates in three Mediterranean woody species following long-term experimental drought. Front. Plant Sci. 4:400. doi: 10.3389/fpls.2013.00400

Rowland, L. J., Ogden, E. L., Takeda, F., Glenn, D. M., Ehlenfeldt, M. K., and Vinyard, B. T. (2013). Variation among highbush blueberry cultivars for frost tolerance of open flowers. HortScience 48, 692-695.

Ruelland, E., Vaultier, M. N., Zachowski, A., and Hurry, V. (2009). Cold signalling and cold acclimation in plants. Adv. Bot. Res. 49, 35-150. doi: 10.1016/S00652296(08)00602-2

Saarinen, T., Lundell, R., and Hanninen, H. (2011). Recovery of photosynthetic capacity in Vaccinium vitis-idaea during mild spells in winter. Plant Ecol. 212, 1429-1440. doi: 10.1007/s11258-011-9918-y 
Sakai, A. (1966). Studies of frost hardiness in woody plants. II. Effect of temperature on hardening. Plant Physiol. 41, 353-359. doi: 10.1104/pp.41.2.353

Sakai, A., and Larcher, W. (1987). "Frost survival of plants. Responses and adaptation to freezing stress," Vol. 62, Ecological Studies (Berlin: Springer Verlag), 321. doi: 10.1007/978-3-642-71745-1

Sakr, S., Alves, G., Morillon, R. L., Maurel, K., Decourteix, M., Guilliot, A., et al. (2003). Plasma membrane aquaporins are involved in winter embolism recovery in walnut tree. Plant Physiol. 133, 630-641. doi: 10.1104/pp.103.027797

Sala, A., Woodruff, D. R., and Meinzer, F. C. (2012). Carbon dynamics in trees: feast or famine? Tree Physiol. 32, 764-775. doi: 10.1093/treephys/tpr143

Saudreau, M., Marquier, A., Adam, B., Monney, P., and Sinoquet, H. (2009). Experimental study of fruit temperature dynamics within apple tree crowns. Agric. For. Meteorol. 149, 362-372. doi: 10.1016/j.agrformet.2008.09.001

Saudreau, M., Sinoquet, H., Santin, O., Marquier, A., Adam, B., Longuenesse, J. J., et al. (2007). A 3D model for simulating the spatial and temporal distribution of temperature within ellipsoidal fruit. Agric. For. Meteorol. 147, 1-15. doi: 10.1016/j.agrformet.2007.06.006

Sauter, J. J., and van Cleve, B. (1991). Biochemical and ultrastructural results during starch-sugar conversion in ray parenchyma cells of Populus during cold adaptation. J. Plant Physiol. 139, 19-26. doi: 10.1016/S0176-1617(11)80158-6

Savvides, A., Van Ieperen, W., Dieleman, J. A., and Marcelis, L. F. M. (2013). Meristem temperature substantially deviates from air temperature even in moderate environments: is the magnitude of this deviation species-specific? Plant Cell Environ. 36, 1950-1960. doi: 10.1111/pce.12101

Scheifinger, H., Menzel, A., Koch, E., and Peter, C. (2003). Trends of spring time frost events and phenological dates in Central Europe. Theor. Appl. Climatol. 74, 41-51. doi: 10.1007/s00704-002-0704-6

Schreiber, S. G., Hamann, A., Hacke, U. G., and Thomas, B. R. (2013). Sixteen years of winter stress: an assessment of cold hardiness, growth performance and survival of hybrid poplar clones at boreal planting site. Plant Cell Environ. 36, 419-428. doi: 10.1111/j.1365-3040.2012.02583.x

Schwarz, W. V. (1970). Der einfluss der photoperiode auf das austreiben, die frosthärte und die hitzeresistenz von zirben und alpenrozen. Flora 159, 258-285.

Siddiqui, K. S., and Cavicchioli, R. (2006). Cold-adapted enzymes. Annu. Rev. Biochem. 75, 403-433. doi: 10.1146/annurev.biochem.75.103004.142723

Silpi, U., Lacointe, A., Kasempsap, P., Thanysawanyangkura, S., Chantuma, P., Gohet, E., et al. (2007). Carbohydrate reserves as a competing sink: evidence from tapping rubber trees. Tree Physiol., 27, 881-889. doi: 10.1093/treephys/27.6.881

Silva-Cancino, M. C., Esteban, R., Artetxe, U., and Plazaola, J. I. G. (2012). Patterns of spatio-temporal distribution of winter chronic photoinhibition in leaves of three evergreen Mediterranean species with contrasting acclimation responses. Physiol. Plant. 144, 289-301. doi: 10.1111/j.1399-3054.2011.01556.x

Sinoquet, H., Le Roux, X., Adam, B., Améglio, T., and Daudet, F. A. (2001). RATP: a model for simulating the spatial distribution of radiation absorption, transpiration and photosynthesis within canopies: application to an isolated tree crown. Plant Cell Environ. 24, 395-406. doi: 10.1046/j.1365-3040.2001.00694.x

Smith, L. C. (1994). The Root in Winter. Ph.D. thesis, University of St Andrews, Fife.

Snyder, R. L., and Melo-Abreu, J. P. (2005). Frost Protection: Fundamentals, Practice and Economics, Vol. 1, Environment and Natural Resources Series. Rome: Food and Agriculture Organization of the United Nations, xiv +223 p.

Snyder, R. L., Melo-Abreu, J. P., and Matulich, S. (2005). Frost Protection: Fundamentals, Practice and Economics, Vol. 2, Environment and Natural Resources Series. Rome: Food and Agriculture Organization of the United Nations, v + $64 \mathrm{p}$.

Sprugel, D. G., Hinckley, T. M., and Schaap, W. (1991). The theory and practice of branch autonomy. Annu. Rev. Ecol. Syst. 22, 309-334. doi: 10.1146/annurev.es.22.110191.001521

Spulak, O., and Balcar, V. (2013). Temperatures at the margins of a young spruce stand in relation to aboveground height. IForest 6, 302-309. doi: 10.3832/ifor0815-006

Stattin, E., Verhoef, N., Balk, P., van Wordragen, M., and Lindstrom, A. (2012). Development of a molecular test to determine the vitality status of Norway spruce (Picea abies) seedlings during frozen storage. New For. 43, 665-678. doi: 10.1007/s11056-012-9320-1

Stephan, J., Sinoquet, H., Dones, N., Haddad, N., Talhouk, S., and Lauri, P. E. (2008). Light interception and partitioning between shoots in apple cultivars influenced by training. Tree Physiol. 28, 331-342. doi: 10.1093/treephys/28.3.331
Steponkus, P. L. (1981). "Responses to extreme temperatures. Cellular and subcellular bases," in Physiological Plant Ecology I, eds L. O. Lange, P. S. Nobel, C. B. Osmond, and H. Ziegler (Berlin Heidelberg: Springer), 371-402.

Swidrak, I., Schuster, R., and Oberhuber, W. (2013). Comparing growth phenology of co-occurring deciduous and evergreen conifers exposed to drought. Flora 208, 609-617. doi: 10.1016/j.flora.2013.09.004

Swindell, W. R. (2006). The association among gene expression responses to nine abiotic stress treatments in Arabidopsis thaliana. Genetics 174, 1811-1824. doi: 10.1534/genetics.106.061374

Tanino, K. K., Kalcsits, L., Silim, S., Kendall, E., and Gray, G. R. (2010). Temperaturedriven plasticity in growth cessation and dormancy development in deciduous woody plants: a working hypothesis suggesting how molecular and cellular function is affected by temperature during dormancy induction. Plant Mol. Biol. 73, 49-65. doi: 10.1007/s11103-010-9610-y

Thitithanakul, S., Petel, G., Chalot, M., and Beaujard, F. (2012). Supplying nitrate before bud break induces pronounced changes in nitrogen nutrition and growth of young poplars. Funct. Plant Biol. 39, 795-803. doi: 10.1071/ FP12129

Thomas, F. M., and Ahlers, U. (1999). Effects of excess nitrogen on frost hardiness and freezing injury of above-ground tissue in young oaks (Quercus petraea and Q. robur). New Phytol. 144, 73-83. doi: 10.1046/j.1469-8137.1999. 00501.x

Thomas, F. M., and Blank, R. (1996). The effect of excess nitrogen and of insect defoliation on the frost hardiness of bark tissue of adult oaks Ann. For. Sci. 53, 395-406. doi: 10.1051/forest: 19960222

Thorn, A. M., and Orians, C. M. (2011). Modeling the influence of differential sectoriality on the photosynthetic responses of understory saplings to patchy light and water availability. Trees $25,833-845$. doi: $10.1007 /$ s00468-0110559-5

Tjoelker, M. G., Oleksyn, J., Lorenc-Plucinska, G., and Reich, P. B. (2009). Acclimation of respiratory temperature responses in northern and southern populations of Pinus banksiana. New Phytol. 181, 218-229. doi: 10.1111/j.14698137.2008.02624.x

Tranquillini, W. (1979). Physiological Ecology of the Alpine Timberline. Berlin: Springer-Verlag. doi: 10.1007/978-3-642-67107-4

Turhan, E., and Ergin, S. (2012). Soluble sugars and sucrose-metabolizing enzymes related to cold acclimation of sweet cherry cultivars grafted on different rootstocks. Sci. World J. 2012, 7. doi: 10.1100/2012/979682

Uemura, M., and Steponkus, P. L. (1994). A contrast of the plasma membrane lipid composition of oat and rye leaves in relation to freezing tolerance. Plant Physiol. 104, 479-496.

Uemura, M., Tominaga, Y., Nakagawara, C., Shigematsu, S., Minami, A., and Kawamura, Y. (2006). Responses of the plasma membrane to low temperatures. Physiol. Plant. 126, 81-89. doi: 10.1111/j.1399-3054.2005.00594.x

Umbanhowar, C. E., Lambert, A. M., and van Delinder, L. (2008). Effects of freezing on Young's modulus for twigs of coniferous and deciduous trees and shrubs. Can. J. For. Res. 38, 394-399. doi: 10.1139/X07-130

Urban, L., Lechaudel, M., and Lu, P. (2004). Effect of fruit load and girdling on leaf photosynthesis in Mangifera indica L. J. Exp. Bot. 55, 2075-2085. doi: 10.1093/jxb/erh220

Usenik, V., Solar, A., Meolic, D., and Stampar, F. (2008). Effects of summer pruning on vegetative growth, fruit quality and carbohydrates of 'Regina' and 'Kordia' sweet cherry trees on 'Gisela 5'. Eur. J. Hortic. Sci. 73, 62-68.

van Cleve, K., Barney, R., and Schlentner, R. (1981). Evidence of temperature control of production and nutrient cycling in two interior Alaska black spruce ecosystems. Can. J. For. Res. 11, 259-274. doi: 10.1139/x81-035

Volpe, G., Lo Bianco, R., and Rieger, M. (2008). Carbon autonomy of peach shoots determined by C-13-photoassimilate transport. Tree Physiol. 28, 1805-1812. doi: 10.1093/treephys/28.12.1805

Wan, X., Zwiazek, J. J., Lieffers, V. J., and Landhäusser, S. M. (2001). Hydraulic conductance in aspen (Populus tremuloides) seedlings exposed to low root temperatures. Tree Physiol. 21, 691-696. doi: 10.1093/treephys/21.10.691

Wargo, P. M. (1972). Defoliation-induced chemical changes in sugar maple roots stimulate growth of Armillaria mellea. Phytopathology 62, 1278-1283. doi: 10.1094/Phyto-62-1278

Wargo, P. M. (1979). Starch storage and radial growth in woody roots of sugar maple. Can. J. For. Res. 9, 49-56. doi: 10.1139/x79-009

Wargo, P. M., Parker, J., and Houston, D. R. (1972). Starch content in roots of defoliated sugar maple. For. Sci. 18, 203. 
Weber, M. E., Pilatti, R. A., Sordo, M. H., Garcia, M. S., Castro, D., and Gariglio, N. F. (2011). Changes in the vegetative growth of the low-chill peach tree in response to reproductive shoot pruning after harvesting. N. Z. J. Crop Hortic. Sci. 39, 153-160. doi: 10.1080/01140671.2011.559255

Weiser, C. J. (1970). Cold resistance and acclimation in woody plants. Hortscience 5, 403-410.

Wibbe, M. L., Blanke, M. M., and Lenz, F. (1994). Respiration of apple trees between leaf fall and leaf emergence. Environ. Exp. Bot. 34, 25-30. doi: 10.1016/00988472(94)90005-1

Wiley, E., Huepenbecker, S., Casper, B. B., and Helliker, B. R. (2013). The effects of defoliation on carbon allocation: can carbon limitation reduce growth in favour of storage? Tree Physiol. 33, 1216-1228. doi: 10.1093/treephys/tpt093

Willaume, M., Lauri, P. E., and Sinoquet, H. (2004). Light interception in apple trees influenced by canopy architecture manipulation. Trees 18, 705-713. doi: 10.1007/s00468-004-0357-4

Wilson, J. D., and Flesch, T. K. (1999). Wind and remnant tree sway in forest cutblocks. III. A windflow model to diagnose spatial variation. Agric. For. Meteorol. 93, 259-282. doi: 10.1016/S0168-1923(98)00121-X

Winkel, T., Lhomme, J. P., Nina Laura, J. P., Alcon, C. M., del Castillo, C., and Rocheteau, A. (2009). Assessing the protective effect of vertically heterogeneous canopies against radiative frost: the case of quinoa on the Andean Altiplano. Agric. For. Meteorol. 149, 1759-1768. doi: 10.1016/j.agrformet.2009. 06.005

Wisniewski, M., Fuller, M., Glenn, D. M., Gusta, L., Duman, J., and Griffith, M. (2002). "Extrinsic ice nucleation in plants-what are the factors involved and can they be manipulated?" in Plant Cold Hardiness: Gene Regulation and Genetic Engineering, eds P. H. Li and E. T. Palva (New York, NY: Kluwer Academic), 211-221.

Witt, W., and Sauter, J. J. (1994). Enzymes of starch metabolism in poplar wood during fall and winter. J. Plant Physiol. 143, 625-631. doi: 10.1016/S01761617(11)81149-1

Wolfe, J., and Bryant, G. (2001). Cellular cryobiology: thermodynamic and mechanical effects. Int. J. Refrig. 24, 438-450. doi: 10.1016/S0140-7007(00)00027-X

Wong, B. L., Baggett, K. L., and Rye, A. H. (2003). Seasonal patterns of reserve and soluble carbohydrates in mature sugar maple (Acer saccharum). Can. J. Bot. 81, 780-788. doi: 10.1139/b03-079

Wong, B. L., Baggett, K. L., and Rye, A. H. (2009). Cold-season patterns of reserve and soluble carbohydrates in sugar maple and ice-damaged trees of two age classes following drought. Botany 87, 293-305.
Wünsche, J. N., Greer, D. H., Laing, W. A., and Palmer, J. W. (2005). Physiological and biochemical leaf and tree responses to crop load in apple. Tree Physiol. 25, 1253-1263. doi: 10.1093/treephys/25.10.1253

Wythers, K. Z., Reich, P. B., Tjoelker, M. G., and Bolstad, P. B. (2005). Foliar respiration acclimation to temperature and temperature variable Q10 alter ecosystem carbon balance. Glob. Change Biol. 11, 369-377. doi: 10.1111/j.13652486.2005.00922.x

Yamada, M., and Takahashi, H. (2004). Frost damage to Hemerocallis esculenta in a mire: relationship between flower bud height and air temperature profile during calm, clear nights. Can. J. For. Res. 82, 409-419.

Yamamoto, T., Nobori, H., Sasaki, H., and Hayasaka, K. (1999). The effects of shading on translocation of C-13-photosynthates between lateral branches during the rapid growth period of cherry, pear, and Japanese persimmon fruit. J. Jpn. Soc. Hortic. Sci. 68, 302-311. doi: 10.2503/jjshs.68.302

Yoshida, S. (1984). Studies on freezing injury of plant cells.1. Relation between thermotropic properties of isolated plasma membrane vesicles and freezing injury. Plant Physiol. 75, 38-42. doi: 10.1104/pp.75.1.38

Yoshida, S., and Uemura, M. (1986). Lipid composition of plasma membrane and tonoplasts isolated from etiolated seedlings of mung bean (Vigna radiata L.). Plant Physiol. 82, 807-812. doi: 10.1104/pp.82.3.807

Zinkan, C. G., Jeglum, J. K., and Harvey, D. E. (1974). Oxygen in water culture influences growth and nutrient uptake of jack pine, black spruce and white spruce seedlings. Can. J. Plant Sci. 54, 553-558. doi: 10.4141/cjps74093

Zweifel, R., Zimmermann, L., and Newbery, D. M. (2005). Modeling tree water deficit from microclimate: an approach to quantifying drought stress. Tree Physiol. 25, 147-156. doi: 10.1093/treephys/25.2.147

Conflict of Interest Statement: The authors declare that the research was conducted in the absence of any commercial or financial relationships that could be construed as a potential conflict of interest.

Copyright (c) 2015 Charrier, Ngao, Saudreau and Améglio. This is an open-access article distributed under the terms of the Creative Commons Attribution License (CC $B Y)$. The use, distribution or reproduction in other forums is permitted, provided the original author(s) or licensor are credited and that the original publication in this journal is cited, in accordance with accepted academic practice. No use, distribution or reproduction is permitted which does not comply with these terms. 